\title{
PENYELESAIAN SENGKETA BATAS LAUT ANTARA PROVINSI KEPULAUAN BANGKA BELITUNG DENGAN PROVINSI KEPULAUAN RIAU
}

\author{
Dispute Resolutions Sea Border Between The Province of Bangka Belitung Islands in Riau \\ Islands Province
}

\author{
Djoko Sulistyono \\ Peneliti Madya pada Pusat Penelitian Pemerintahan Umum dan Kependudukan \\ Badan Penelitian dan Pengembangan (Badan Litbang) Kementerian Dalam Negeri \\ Jl. Kramat Raya No. 132 - Senen, Jakarta \\ E-mail: djoksul2013@gmail.com,Tlp.085216019444 \\ Dikirim: 13 Maret 2014; direvisi: 6 April 2014; disetujui: 12 Mei 2014
}

\begin{abstract}
Abstrak
Penelitian ini dilakukan dan didasari atas adanya "kengototan" klaim dari provinsi Bangka Belitung dan provinsi Kepulauan Riau bahwa Gugus Pulau Tujuh, yaitu wilayah yang disengketakan tersebut merupakan wilayahnya. Oleh karena itu, penelitian ini kiranya dapat memberikan suatu solusi dalam penyelesaian sengketa batas laut di antara ke dua provinsi tersebut. Penelitian ini menggunakan metode kualitatif dengan pendekatan deskriptif analitis. Metode ini digunakan, karena fenomena konstelasi sengketa batas antar daerah (termasuk batas laut) dipandang bersifat multidimensional. Data-data yang diambil dari penelitian lapangan baik itu data primer maupun sekunder, dilakukan melalui wawancara mendalam dengan informan kunci terpilih dan observasi lapangan serta dikombinasikan dengan studi kepustakaan, melalui penelusuran buktibukti otentik sengketa pada masa lalu yang relevan. Pemerintah (pihak Kementerian Dalam Negeri) harus segera menyelesaikan masalah sengketa segmen batas laut di gugusan Pulau Tujuh yang melibatkan pihak Pemerintah Provinsi Kepulauan Bangka Belitung dengan Pemerintah Provinsi Kepulauan Riau dengan mengacu pada empat pendekatan, yaitu a) Sisi Historis; b) Yuridis; c) Pemerintahan; dan d) Sisi Sosial Budaya. Dan ditambah dengan tidak menafikan keinginan masyarakat yang tinggal di pulau tersebut, diharapkan dapat diapresiasi oleh Pemerintah dengan baik.

Kata kunci: penyelesaian sengketa, segmen batas laut
\end{abstract}

\begin{abstract}
This research was conducted and based on the existence of "persistence" claims of the province of Bangka Belitung islands and Riau islands province that seven islands groups, which is disputes region territory. Therefore, this study would be likely to provide a solution in resolving the dispute between the two provinces. This study uses qualitative methods with descriptive analytical approach. This method is used, because the phenomenon of inter-regional constellation boundary disputes (including sea boundary) is considered to be multidimensional. The data were taken from both the research field of primary data and secondary data, conducted through in-depth interviews with selected key informants and field observations, and combined with the study of literature through a search of the authentic evidence disputes the relevant past. Government (the Ministry of Home Affairs) should immediately resolves disputes in the sea boundary segment cluster seven islands involving the provincial government Bangka Belitung islands and Riau islands provincial government with reference to the four approaches, namely: a) the historical side; b) juridical side; $c$ ) side of the rule; d) the social side of the culture. And coupled with the desire not to deny the people who live on the islands so expect to be appreciated by the government well.

Keywords: dispute resolution, marine boundary segment
\end{abstract}

\section{PENDAHULUAN}

Persoalan batas memang multi-dimensi yang melibatkan aspek legal, teknis, dan sosial ekonomi. Sengketa batas bisa menimbulkan berbagai persoalan yang terkait setidaknya dengan ketiga aspek tersebut. Peralihan sistem pemerintahan sentralisasi kepada desentralisasi merupakan titik awal dilaksanakannya konsep otonomi daerah di Indonesia. Undang-Undang (UU) Nomor 32 Tahun 2004 tentang pemerintahan daerah, telah mengatur penentuan dan penegasan batas wilayah baik di darat maupun di laut. Untuk mendukung hal tersebut, Menteri Dalam Negeri telah mengeluarkan Peraturan Menteri Dalam Negeri
(Permendagri) Nomor 1 Tahun 2006 tentang Pedoman Penegasan Batas Daerah. Perlu diperhatikan bahwa istilah "penentuan" dan "penegasan" memiliki pengertian yang berbeda ${ }^{1}$.

\footnotetext{
${ }^{1}$ Penentuan mengacu kepada penetapan batas di atas peta. Sedangkan penegasan adalah penetapan titik-titik batas di lapangan. Dengan kata lain, penegasan adalah tindak lanjut dari penentuan batas. Hal ini ditegaskan dalam Permendagri yang menyebutkan bahwa "penegasan batas daerah dititik beratkan pada upaya fisik di lapangan.(Pasal 2 ayat 1). Penegasan batas darat meliputi beberapa langkah. Antara lain, melalui: 1) penelitian dokumen, 2) pelacakan batas, 3) pemasangan pilar batas, 4) pengukuran dan penentuan posisi pilar
} 
Terkait kewenangan daerah di wilayah laut, alasan perlunya batas laut adalah untuk menyelesaikan tumpang tindih klaim (overlapping claim) daerah di wilayah laut. Klaim daerah di dalam tataran NKRI yang merupakan suatu Negara kepulauan, sebenarnya wilayah laut yang berada di antara pulau-pulau di nusantara ini merupakan satu kesatuan yang utuh dari NKRI. Jadi pada prinsipnya, Pemerintah Daerah tidak berhak atas kewenangan laut, dan yang paling tepat dalam mengurusi kewenangan laut adalah Pemerintah Pusat. Hanya saja, dijelaskan dalam UU Nomor 32 Tahun 2004, sebuah provinsi yang memiliki laut berhak atas kewenangan laut sejauh 12 mil laut dari garis dasar (biasanya garis pantai). Hal ini tentu dapat dipahami, bahwa kewenangan atas laut tersebut harus dilakukan sepengetahuan Pemerintah Pusat. Hanya saja untuk menghindari sengketa yang berada diperairan, maka perlu pihak-pihak yang bersengketa atau berkepentingan, haruslah berkoordinasi dengan Pemerintah Pusat.

Permendagri tersebut juga menegaskan bahwa ada enam langkah utama yang harus dilakukan dalam penentuan batas wilayah laut, yaitu: penelitian dokumen, pelacakan batas, pemasangan pilar dan titik acuan, penentuan titik awal dan garis dasar, pengukuran dan penentuan batas, dan pembuatan peta batas. Berbeda dengan batas darat, pemasangan pilar tidak dilakukan di titik batas, yang notabene di tengah laut, tetapi di darat (pantai) yang dijadikan referensi dalam menentukan posisi titik batas maritime antar provinsi.

Secara teknis, aspek yang sangat penting dalam penegasan batas daerah adalah geodasi atau survey pemetaan. Hal yang harus diperhatikan dalam penentuan dan penegasan batas adalah adalah yang akan digunakan, teknologi yang dipilih terkait kualitas hasil yang diharapkan, serta partisipasi masyarakat yang secara langsung akan terkena dampak akibat adanya penegasan batas tersebut.

Untuk darat, misalnya, batas bisa ditentukan dengan unsur alam (seperti: sungai, watershed, danau, dan lain-lain), dan unsur buatan (seperti: jalan, rel kereta, saluran irigasi, pilar batas, dan lain-lain). Penggunaan unsur-unsur alam akan mengakibatkan batas menjadi dinamis akibat perubahan bentang alam. Hal inilah yang mengakibatkan bergesernya batas antara antar daerah.

Untuk batas dari unsur buatan, seperti pilar batas, penentuan posisi yang akurat merupakan hal penting. Dalam kaidah geodasi, penentuan posisi pilar batas harus dinyatakan dalam koordinat dengan datum dan system proyeksi yang jelas. Angka koordinat tanpa spesifikasi datum yang pasti sesungguhnya tidak menjelaskan apa-apa. Koordinat yang sama jika

batas, dan 5) pembuatan peta batas. Dalam penegasan batas ini, seperti yang secara eksplisit disebutkan dalam Permendagri Nomor 1 Tahun 2006, Pasal 4 ayat 2, menyebutkan wajib diterapkan prinsip geodasi. Hal ini jelas terlihat ketika kita tahu bahwa peran surveyor geodasi sangat penting dalam penegasan batas daerah datumnya berbeda akan mengacu pada posisi yang berbeda di lapangan. Sebaliknya, suatu posisi tertentu di lapangan bisa dinyatakan dengan koordinat yang berbeda jika datum dan sistem proyeksinya berbeda.

Terkait dengan ketelitian posisi/ koordinat titik batas, Permendagri yang ada sudah memberikan spesifikasi yang rinci. Ketelitian ini tentunya terkait dengan teknologi dan metode penentuan posisi yang digunakan. Penentuan posisi dengan Global Positioning System (GPS), yaitu: penentuan posisi dengan satelit, adalah salah satu yang direkomendasikan. Namun demikian, penggunaan GPS sendiri harus memperhatikan jenis dan metode pengukurannya untuk mendapatkan posisi dengan ketelitian yang disyaratkan. Pengukuran dengan GPS navigasi (handheld) seperti yang sekarang popular di masyarakat berupa piranti seukuran handphone tentu saja menghasilkan ketelitian posisi yang lebih rendah dibandingkan penggunaan GPS jenis geodetic yang dilakukan secara relative (deferential). Tim Penegasan Batas di tingkat provinsi maupun pusat harus memahami hal ini.

Penentuan dan penegasan batas merupakan agenda penting dalam melaksanakan otonomi daerah. Dengan diraihnya otonomi daerah, baik berdasarkan UU no. 22 Tahun 1999 dan UU no.32 Tahun 2004, maka Pemerintah Daerah menerima Dana Alokasi Umum (DAU) dan Dana Alokasi Khusus (DAK). Untuk menerima DAU tersebut, salah satu indikatornya adalah dengan melihat luas wilayah suatu daerah. Untuk itu, maka luas wilayah suatu daerah menjadi sangat penting dihitung berdasarkan batasbatas daerah yang jelas. Dengan begitu, bahwa perhitungan DAU, berdasarkan atas luas wilayah yang jelas dan pasti. DAU yang diterima suatu daerah seharusnya bukan menciptakan keadilan bagi daerah yang berbentuk kepulauan di mana luas daratannya lebih sempit daripada luas wilayah laut yang menghubungkan pulau-pulau dalam provinsi tersebut. Meskipun sinyalemen itu masih merupakan wacana, akan tetapi hal ini harus menjadi kajian serius dari berbagai pihak. Oleh karena itu, hal ini dapat mengindikasikan bahwa penentuan (delimitasi) batas maritim antar daerah menjadi penting artinya.

Prinsip Negara Kesatuan Republik Indonesia (NKRI) yang berbentuk kepulauan, haruslah menjadi acuan kita semua agar kita tidak dipecah belah oleh berbagai kepentingan. Sebagai suatu Negara kepulauan/ maritim, bahwa penentuan batas maritim ini adalah hanya sebatas penegasan batas suatu daerah. Kewenangan penuh untuk mengelola perairan di nusantara ini berada pada Pemerintah Pusat, dan tidak ada asumsi untuk memberikan kewenangan penuh kepada daerah untuk menguasai laut. Hal seperti ini harus benar-benar dicamkan oleh Pemerintaha Daerah.

Sengketa batas antar daerah telah menimbulkan hubungan antar daerah itu kurang harmonis. Hubungan yang buruk kian terasa tatkala di kawasan batas yang disengketakan itu terkandung sumber daya 
alam. Karenanya, diperlukan kerja sama antar daerah yang antara lain untuk menyelesaikan sengketa batas. Terjadinya konflik batas antar daerah, baik antar provinsi, kabupaten/ kota maupun antar desa/ kelurahan, akan berdampak pada kurang harmonisnya hubungan antar pemerintah daerah.

Adanya kejadian rebutan sumber daya alam, yang terdapat di wilayah perbatasan antar daerah, juga berimbas pada aspek perizinan, di mana terjadi tumpang tindih penerbitan surat perizinan pengelolaan sumber daya alam tersebut. Persoalan lain yang muncul, terkait penerbitan surat keterangan dan bukti atas tanah yang terdapat di wilayah perbatasan antar daerah tersebut.

Tulisan ini didasarkan atas sengketa batas laut antar dua provinsi di Sumatra, yaitu antara Provinsi Kepulauan Bangka Belitung dengan Provinsi Kepulauan Riau, yang berlarut-larut dan belum terselesaikan secara tuntas. Penelitian ini akan berusaha mengelaborasi lebih dalam sengketa segmen batas laut yang diklaim oleh Provinsi Kepulauan Riau dan Provinsi Kepulauan Bangka Belitung. Dan sampai dengan penelitian ini dilakukan, ke dua provinsi tersebut "sama-sama ngotot" bahwa Gugus Pulau Tujuh, yaitu wilayah yang disengketakan tersebut merupakan wilayahnya. Hal ini tentu tidak dapat dibiarkan berlarut-larut, karena itu diharapkan penelitian ini dapat memberikan suatu alternatif solusi di dalam penyelesaian sengketa batas laut bermasalah antara Provinsi Kepulauan Bangka Belitung (Babel) dengan Provinsi Kepulauan Riau. Dengan adanya alternatif solusi tersebut maka diharapkan penyelesaian sengketa batas antar daerah tersebut dapat diselesaikan secara proporsional, dan dapat diterima oleh pihak-pihak yang bersengketa. Pemerintah Pusat (Kementerian Dalam Negeri) dengan begitu dapat menyelesaikan permasalahan sengketa batas laut ke dua provinsi tersebut, dengan mempertimbangkan adanya masukan-masukan yang diberikan lembaga-lembaga penelitian, termasuk masukan dari Pusat Penelitian dan Pengembangan Pemerintahan Umum dan Kependudukan Badan Penelitian dan Pengembangan Kementerian Dalam Negeri (Puslitbang Pumduk Badan Litbang Kemendagri) di mana penelitian ini diberikan dana penelitian.

Salah satu hal yang penting bagi pemerintah daerah adalah bahwa penentuan dan penegasan batas merupakan agenda yang harus dijadikan suatu prioritas. Dalam konteks ini, pertanyaan penelitian yang diketengahkan adalah: Bagamana memberikan suatu alternatif solusi penyelesaian segmen batas laut bermasalah antara Provinsi Kepulauan Bangka Belitung dengan Provinsi Kepulauan Riau yang dapat ditawarkan, sehingga pihak-pihak yang bersengketa tersebut dapat menerima penyelesaian yang dilakukan oleh Pemerintah Pusat (Kementerian Dalam Negeri)?

Tulisan ini didasarkan atas penelitian yang dilakukan pada tahun 2011, dan diharapkan berusaha memberikan suatu rekomendasi kebijakan bagi
Pemerintah untuk digunakan sebagai suatu alternatif solusi penyelesaian segmen batas laut bermasalah antara Provinsi Kepulauan Bangka Belitung dengan Provinsi Kepulauan Riau.

\section{METODE PENELITIAN}

Metodologi yang digunakan dalam penelitian ini adalah metode pendekatan kualitatif dan deskriptif analitis. Metode ini diarahkan kepada pendekatan kualitatif. Pendekatan kualitatif dianggap merupakan pendekatan yang relatif tepat, karena fenomena konstelasi sengketa batas antar daerah dipandang bersifat multidimensional. Penelitian ini berupa penelitian lapangan (field research) dengan metode pengambilan data primer maupun sekunder, yang berupa wawancara mendalam dan pengamatan yang dikombinasikan dengan studi kepustakaan.

\section{Rancangan Penelitian}

Penelitian ini untuk mencari suatu alternatif solusi penyelesaian segmen batas laut bermasalah antara Provinsi Kepulauan Bangka Belitung dengan Provinsi Kepulauan Riau. Oleh karena itu, pada Penelitian ini, akan melihat pada saat ini (existing condition) maupun pada keadaan yang diharapkan (expected condition), dalam rangka mengurangi konflik antar daerah. Penelitian ini didasarkan pada suatu kerangka berfikir logis yang mempunyai argumentasi ilmiah. Kerangka pikir yang melandasi penelitian ini disajikan pada gambar 1 .

Disain penelitian ini digunakan untuk mendapatkan data (baik primer maupun sekunder) mengenai penyelesaian sengketa batas antar daerah yang seharusnya (expected condition) dengan penyelesaian sengeketa batas daerah yang selama ini dimiliki terkait dengan adanya penyelesaian dalam birokrasi pemerintah daerah (existing condition) dikaitkan dengan situasi dan kondisi di daerah/ lokasi penelitian.

\section{Metode Pengumpulan Data}

Data yang dibutuhkan dalam penelitian ini adalah data primer dan data sekunder.

1. Data Primer, yaitu data yang diperoleh secara langsung dari responden terpilih, di mana data tersebut belum diolah. Data primer dikumpulkan dengan suatu wawancara yang mendalam (indepth interview), dan observasi ke lapangan (lokus penelitian).

2. Data Sekunder, yaitu data yang diperoleh dari kedua pihak yang bersengketa. Data tersebut berupa tulisan-tulisan baik berupa laporan penelitian sebelumnya, peraturan perundangundangan dan dokumen-dokumen pendukung terkait lainnya, seperti Anggaran Pendapatan Belanja Daerah (APBD) dan realisasinya, Provinsi dan Kabupaten/Kota Dalam Angka, Produk Domestik Regional Bruto (PDRB), Data Statistik yang menjadi objek penelitian, kliping- 


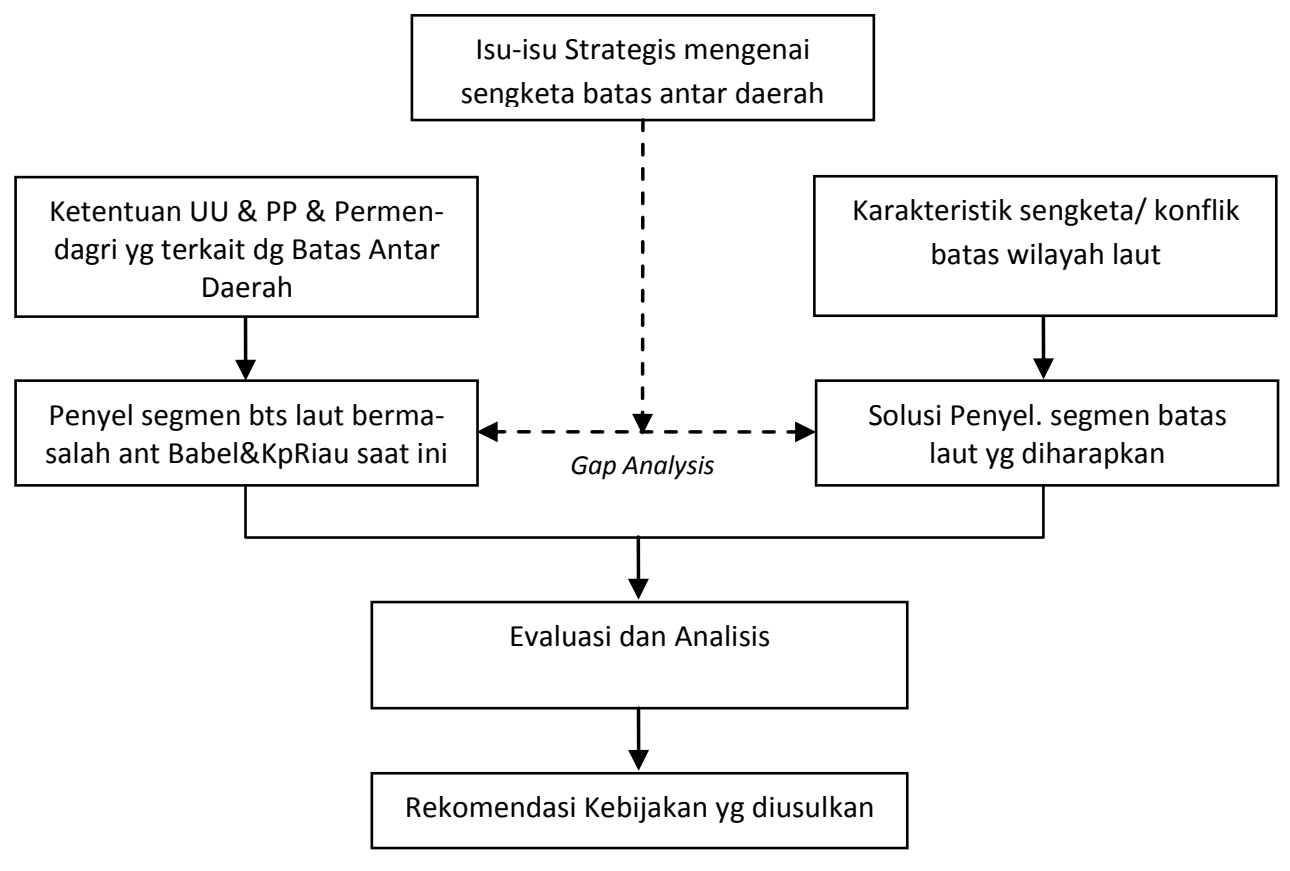

Gambar 1: Kerangka Pikir

kliping koran lokal dan nasional serta sumbersumber lain yang relevan.

Pada penelitian ini menggunakan studi kasus (case study) yang terkait dengan sengketa segmen batas laut antara Provinsi Kepulauan Bangka Belitung dengan Provinsi Kepulauan Riau. Dua Provinsi ini diambil sebagai studi kasus karena memang pada saat dilakukan penelitian masih bersengketa menyangkut segmen batas laut tersebut. Pada penelitian yang dilakukan pada tahun 2011 ini, fokus dan lokus penelitian diambil sengketa segmen batas laut yang antara Provinsi Kepulauan Bangka Belitung dengan Provinsi Kepulauan Riau yang memperebutkan kawasan gugus Pulau Tujuh. Oleh karena itu, provinsi yang kemudian ditetapkan sebagai daerah atau lokus penelitian ini adalah:

1. Kepulauan Bangka Belitung; dan

2. Kepulauan Riau.

\section{Nara Sumber (Key resources persons) \\ 1. Tingkat Pusat}

Nara sumbernya berasal dari: Direktorat Jendral Kementerian Dalam Negeri, PUM), Perguruan Tinggi (Pakar Sosial Politik, Hukum, Sumber Daya Alam, dan disiplin ilmu lainnya yang terkait), Pusat Penelitian Politik Lembaga Ilmu Pengetahuan Indonesia, Bakorkamla, Bakosurtanal dan pihak lainnya yang mengetahui sengketa segmen batas laut

\section{Tingkat Provinsi}

Nara sumbernya berasal dari: Biro Pemerintahan Pemerintah Provinsi Kepri dan Babel, Perguruan Tinggi (Pakar Sosial Politik, Hukum, Sumber Daya Alam dan disiplin ilmu lainnya), Lembaga Swadaya Masyarakat (LSM), DPRD Provinsi Kepri dan Babel (terutama Komisi yang membidangi dan ikut menangani permasalahan sengketa batas), Pers lokal, Bakorkamla Daerah, Bakosurtanal Daerah dan Tokoh Masyarakat, serta pihak lainnya yang peduli dan terkait dengan sengketa segmen batas laut di lokasi penelitian.

\section{Tinjauan Pustaka}

Secara teoretis, Lawrence Pratchett mengatakan dalam tulisannya Local Autonomy, Local Democracy and the 'New Localism (2004) ${ }^{2}$. Kedaulatan negara dan kebutuhan menjaga keutuhan wilayah negara tentu mengharuskan campur tangan pemerintah pusat. Pemerintah pusat pasti tidak menghendaki ada daerah yang bebas sama sekali dari campur tangannya. Karena itu, dimensi ini tidak dipahami sebagai kewenangan penuh atas suatu wilayah, melainkan kewenangan (penuh) dalam urusan-urusan tertentu di wilayah yang bersangkutan. Ini pun masih memancing perdebatan.

Sebagaimana diketahui, pemerintah daerah (local government) merupakan suatu entitas di tengahtengah entitas-entitas atau pribadi-pribadi lainnya

\footnotetext{
2 Otonomi daerah dapat diinterpretasi dalam tiga dimensi: freedom from, freedom to, dan perefleksian (kebangkitan) identitas lokal. Interpretasi pertama menekankan pentingnya dimensi kewenangan yang dimiliki daerah atau diskresi, yang dimaknai bebas dari campur tangan pemerintah pusat. Kewenangan ini harus dijamin melalui penetapan ketentuan formal. Semakin besar kewenangan yang dimiliki daerah, berarti semakin besar pula otonominya. Tentu interpretasi ini bisa menjadi sensitif, terutama bila dikaitkan dengan konsep kedaulatan negara dan kebutuhan menjaga keutuhan wilayah, karena dengan penekanan pada freedom from seakan-akan setiap daerah ingin berdaulat sendirisendiri.
} 
yang ada di dalam suatu negara. Dari sisi/ segi hukum, pemerintah daerah (pemda) adalah badan hukum publik, yaitu suatu pribadi hasil rekayasa hukum (persoonrecht). Sebagai suatu pribadi, maka dalam menjalankan kehidupannya pemda memiliki sebagian dari kemampuan yang dipunyai pribadi alamiah (manusia-natuurlijk persoon), yang terpenting adalah kemampuan melakukan perbuatan-perbuatan hukum, seperti membuat perjanjian-perjanjian dengan sesame badan hukum publik atau badan hukum perdata. Dilihat dari segi entitas pemda ini, maka Negara Kesatuan Republik Indonesia (NKRI) adalah suatu masyarakat yang anggotanya terdiri individu-individu yang bernama pemda.

Pemda selaku individu mempunyai dimensidimensi yang kental mewarnai kepribadiannya (Nitibaskara, TRR., 2002). Menurut Aries Djaenuri (1999), Local Government secara konseptual memiliki berbagai dimensi: ${ }^{3}$

\footnotetext{
3 Dimensi Sosial; Konsep Pemda dipandang sebagai suatu kelompok orang yang terorganisir, yang diam dalam suatu wilayah dengan batasan geografis tertentu, serta memiliki ciri-ciri tertentu pula. Pemerintahan lokal tersebut selanjutnya dipengaruhi oleh sosial budaya masyarakat setempat.
}

Dimensi Ekonomi, Pemda dipahami sebagai organisasi tertentu yang memiliki ciri tertentu yang terkait erat dengan kondisi potensi dari daerah tertentu. Umumnya dalam pembangunan Pemda justru potensi ini yang perlu mendapat perhatian, sebagai contoh setiap penyerahan urusan harus senantiasa disesuaikan dengan kondisi potensi daerah yang bersangkutan.

Dimensi Geografi; Pemda sebagai suatu unit organisasi yang memiliki ciri-ciri geografi tertentu, mempunyai keadaan fisik, demografi, dan potensi ekonomi tertentuyang dalam operasional ciri-ciri tersebut punya pengaruh terhadap pembangunan, kebijaksanaan, pelaksanaan administrasi, dan penetapan hak-hak dari Pemda yang bersangkutan.

Dimensi Hukum; Pemda sebagai unit badan hukum publik. Dalam kedudukan ini, Pemda di samping sebagai agen dari Pemerintah juga mewakili pelaksanaan kepentingan masyarakat. Artinya, dalam batas-batas tertentu Pemda diberi dan diserahi urusanurusan dari pemerintahan Negara untuk mengatur dan mengelolanya.

Sebagai badan hukum publik, Pemda diberi wewenang mengurus rumah tanggganya sendiri sekaligus untuk memiliki asset atau kekayaan sendiri serta mewakili organisasinya di dalam dan di luar pengadilan.

Dari dimensi hukum ini memiliki tiga ciri, yaitu:

- Keberadaan Pemda itu harus merupakan satu kesatuan yang terorganisir dan memiliki organisasi sendiri serta memiliki otonomi;

- Memiliki Pemda sendiri itu dicerminkan dengan dimilikinya satu Badan Perwakilan Rakyat;

- Memiliki hak untuk melakukan perjanjian dengan pihak ketiga atau pihak luar.

Dimensi Politik; Pemda mempunyai hubungan langsung dengan aspek-aspek atau merupakan bagian dari Sistem Politik Negara yang bersangkutan. Dalam pelaksanaan fungsinya, Pemda merupakan agen dari pemerintahan Negara. Dengan kata lain, Pemda merupakan suatu
Dengan berlakunya UU Nomor 22 Tahun 1999 dan kemudian UU Nomor 32 Tahun 2004, jati diri kepribadian Pemda dengan segala dimensinya semakin dipertegas, utamanya bagi kabupaten/ kota. Demikian tegasnya, sehingga setiap kabupaten/ kota menjadi figur seolah-olah berdiri sendiri sebagai "miniatur" negara. Penegasan oleh UU ini, akan memperlihatkan potret yang sesungguhnya keadaan jati diri setiap Pemda. Di sini yang lemah, akan tampak kelemahannya, sedangkan yang kuat akan semakin terlihat kekuatannya. Begitu pun, dengan yang miskin, dan yang kaya akan semakin terlihat.

Di dalam pergaulan antar Pemda, keadaan ini tentunya akan memicu persaingan persaingan. Sudah barang tentu, persaingan yang diharapkan adalah persaingan yang sehat, sehingga setiap daerah dapat berkembang ke arah yang lebih baik dari pada sekarang. Akan tetapi sebagaimana umumnya persaingan, bisa juga terjadi penyimpangan yang kemudian mendatangkan konflik antara pihak-pihak yang terlibat dalam kompetisi. Bila nilai-nilai yang dibawa oleh UU Nomor 22 Tahun 1999 dan UU Nomor 32 Tahun 2004 disikapi secara keliru, bisa jadi justru akan mendatangkan konflik antar Pemda.

Sumber ketegangan antar Pemda, barangkali yang terbanyak akan muncul dari penerapan pasal mengenai wilayah, dan pasal mengenai kewenangan daerah. Kedua pasal ini antara lain: memberikan hak menguasai atau mengelola lautan kepada daerah Provinsi berhak berkuasa sejauh 12,3 mil laut, sedangkan Kabupaten 4,3 mil laut (Nitibaskara, TRR., 2002: 82).

Tri Ratnawati (peneliti LIPI) mengatakan bahwa wacana yang berkembang di Pemerintah Provinsi Babel pada tahun 2005 menunjukkan adanya reaksi yang mendua mengenai wewenang Pemda di bidang kelautan. Sebagian pejabat setuju dan sebagian lainnya tidak setuju dengan "pengkavlingan" wilayah laut (2006: 316-319). Selain itu juga dikatakan olehnya, bahwa di tingkat pemerintah pusat, salah satu pandangan yang menghendaki wilayah laut sebagai wilayah nasional yang tidak boleh dibagi-bagi adalah pendapat Dewan Maritim Nasional Departemen Kelautan dan Perikanan (DMI DKP) di Jakarta sebagai berikut: ${ }^{4}$

mekanisme yang terintegrasi untuk pemerintahan suatu Negara dan juga terbentuk sebagai badan hukum publik. Dimensi Administrasi; Pemda merupakan suatu organisasi pemerintahan sendiri (self government), artinya: mempunyai hak untuk mengatur, hak untuk menyelenggarakan, dan hak untuk mengurus.

4 "Memberikan wewenang kepada daerah untuk mengatur di wilayah laut menyebabkan terpisah-pisahnya aturan yang berlaku di laut. Di lain pihak berbagai fungsi di laut tidak dapat di pilah-pilah antara daerah-daerah. Begitu pula kekayaan laut tertentu tidak dapat diidentifikasikan dengan wilayah tertentu. Dapat pula ditambahkan, wilayah laut mudah sekali terkait dengan kegiatan internasional seperti pelayaran. Karena itu, semestinya wewenang di wilayah laut tidak dipilah- 
Selanjutnya, peneliti LIPI tersebut mengatakan, bahwa DMI memberikan semacam jalan keluar dengan mengatakan: "Apakah tidak seyogyanya daerah otonom hanya diberi hak menikmati kekayaan laut tanpa harus memiliki kekuasaan atas laut sebagai teritorialnya ?" (Dokumen DMI DKP, Jakarta, 2004). Hal ini memang sebagai Negara kepulauan, tentunya yang memiliki kekuasaan atas laut adalah Negara.

Sebaliknya, pendapat yang mendukung pembagian kewenangan wilayah laut berpendapat demikian: ${ }^{5}$

Tri Ratnawati mensinyalir, guna melindungi wilayah laut dari penyelundupan (terutama pasir timah) dan pencurian ikan oleh pihak-pihak dari dalam dan luar negeri yang merugikan negara milyaran rupiah, Pemda Provinsi Kepulauan Babel (bekerja sama dengan TNI-AL dan pihak swasta) melakukan kesepakatan membangun kapal pengaman wilayah laut. Pembuatan KAL-35 meter yang dibiayai oleh Pemda Provinsi Kepulauan Babel senilai sekitar 12 milyar rupiah (Tahun anggaran 2003 dan 2004), saat ini hampir selesai dilakukan dengan PT Marinamata Gemanusa sebagai pelaksana proyek (Laporan Pertanggungjawaban Gubernur Kepulauan Babel Tahun 2003). Pekerjaan ini berdasarkan surat

pilah, melainkan satu kesatuan pengaturan secara nasional. Dalam kerangka Nomor 22 Tahun 1999 dan Nomor 32 Tahun 2004, wewenang di wilayah laut paling tidak hampir semuanya bersifat lintas kabupaten dan atau kota. Karena itu, kalaupun ada wewenang otonom di laut, maka wewenang otonomi laut mestinya di tingkat provinsi, bukan di kabupaten dan atau kota. Dengan demikian, hanya akan ada dua wewenang di laut, yaitu: Pusat dan Provinsi. Apabila pesisir dipandang sebagai bagian dari wilayah laut, maka wewenang daerah pesisir dengan sendirinya masuk otonomi provinsi. Tetapi, kalau daerah pesisir dipandang sebagai wilayah darat, ada kemungkinan menjadi otonomi kabupaten dan atau kota, kecuali yang bersifat lintas kabupaten dan atau kota (Dokumen DMI DKP, Jakarta, 2004).

5 "Pada saat desentralisasi dihujat habis-habisan di Indonesia, di jurnal-jurnal dan forum internasional, konsep desentralisasi kelautan justru disanjung-sanjung. Umumnya mereka berangkat dari fakta rusaknya sumber daya akibat sentralisasi manajemen sumber daya kelautan. Sentralisasi telah mengurangi "sense of stewardship" para nelayan dan pemerintah daerah terhadap laut. Di sisi lain, "enforcement cost" pengelolaan oleh negara sangatlah tinggi, dan ternyata negara pun tak mampu menanggung beban itu. Sementara itu desentralisasi dianggap memberikan ruang bagi masyarakat untuk berpartisipasi dalam pengelolaan sumber daya. Sehingga mendorong masyarakat untuk turut bertanggung jawab terhadap keberlanjutan sumber daya kelautan. Jelaslah bahwa desentralisasi kelautan secara secara teoritik memang merupakan suatu tuntutan, baik dalam kerangka peningkatan kesejahteraan maupun keberlanjutan sumber daya (Indra J.Piliang, Dendi Ramdani, dan Agung Pribadi, 2003: 304, 310).
KASAL RI No.B/468/X/2002 tanggal 1 Oktober 2002, perihal kerja sama dan partisipasi daerah dengan Angkatan Laut RI, juncto Surat Menhankam RI No.B/64/M/I/ 2003, tanggal 31 Januari 2003, perihal Rekomendasi Dukungan Pembangunan Kapal Patroli TNI-AL (KAL) yang disampaikan kepada para Gubernur Seluruh Indonesia yang antara lain berbunyi: “...mengingat terbatasnya kemampuan pengamanan dan penegakan hukum di wilayah laut yuridiksi nasional yang diakibatkan oleh terbatasnya kemampuan Negara dan penyediaan anggaran bagi sektor pertahanan, maka diperlukan partisipasi dan kerja sama dengan Pemerintah Daerah. Di samping itu Rakorgub se-Wilayah Sumatra juga merekomendasikan pengamanan pantai dan pesisir Laut Sumatra diserahkan kepada Gubernur Kepulauan Bangka Belitung (Harian Kompas, 25 Juli 2003).

Bila dilihat dari maksud baik pembangunan kapal tersebut untuk menambah armada guna keamanan wilayah laut maka pantaslah semua pihak memberikan apresiasi terhadap Pemprov. Kepulauan Babel. Namun bila ditinjau dari siapa yang bertanggung jawab atas keamanan wilayah laut, maka jelaslah kewenangan keamanan itu menurut UU No.22 Tahun 1999 dan UU No.32 Tahun 2004, masih termasuk dalam wilayah kewenangan Pemerintah Pusat. Dalam UU tersebut disebutkan adanya 5 (lima) kewenangan Pusat yang disentralisasi yang mencakup bidang-bidang: 1) Pertahanan dan Keamanan (Hankam); 2) moneter dan keuangan; 3) peradilan; 4) hubungan luar negeri; dan 5) agama (UU Nomor 22 Tahun 1999).

Berkaitan dengan apa-apa yang telah dijelaskan di bagian muka, maka bila terjadi sengketa batas antar daerah di wilayah perairan dalam NKRI, maka penyelesaian sengketanya harus memperhatikan koridor tersebut. Dalam arti, Kepulauan Nusantara yang bernama Indonesia, yang membentang dari Sabang sampai Meurauke dan dari Pulau Miangas sampai Pulau Rote merupakan satu kesatuan dan tidak terpisahkan satu sama lain. Di sini, berarti Wawasan Nusantara yang juga menjadi Pedoman bagi Negara kepulauan harus dipahami secara benar baik, pemerintah daerah, pemerintah Pusat, serta berbagai kalangan masyarakat lainnya. Wilayah perairan tentunya tidak dimaksudkan untuk memisahkan satu daratan dengan daratan lainnya, akan tetapi sebagai suatu penyambung daratan satu dengan daratan lainnya.

Keluarnya UU no. 17 Tahun 1985, yang mengatur ketentuan-ketentuan Perairan Nusantara dan Wilayah Zona Ekonomi Eksklusif (ZEE), maka luas wilayah laut Indonesia adalah $75 \%$ dari seluruh wilayah Republik Indonesia. Wilayah laut ini jadi penentu integritas nasional juga sebagai sarana perhubungan antar pulau serta merupakan kekayaan sumber daya yang dapat dimanfaatkan untuk berbagai macam kegiatan seperti: perikanan, pertambangan lepas pantai, pariwisata dan sebagainya. Namun demikian, laut menjadi tidak ada artinya apabila tidak 
dikelola dan dimanfaatkan secara arif oleh manusia. Oleh karena itu, penyelesaian masalah sengketa segmen batas laut antara Kepulauan Bangka Belitung dengan Kepulauan Riau harus dapat diselesaikan dengan melihat berbagai macam faktor yang melingkupinya dan memperhatikan keutuhan NKRI. Hal ini diartikan bahwa kedua provinsi kepulauan tersebut merupakan bagian dari Negara Indonesia yang "berbhineka tunggal ika". Jadi ditekankan betul, bahwa kedua kepentingan provinsi kepulauan tersebut harus diletakkan di bawah kepentingan yang lebih besar lagi, yaitu kepentingan nasional bangsa Indonesia.

\section{HASIL DAN PEMBAHASAN}

\section{Provinsi Bangka Belitung}

\section{a. Dari Sisi Historis}

Secara tradisional Perairan Gugusan Kepulauan Tujuh secara tradisional merupakan wilayah penangkapan ikan nelayan warga Provinsi Bangka Belitung, dan secara ekonomi penduduk Desa Pekajang lebih banyak berhubungan dengan warga Kecamatan Belinyu, Kabupaten Bangka, yang berjarak kurang lebih 30 mil laut, bila dibandingkan dari Kecamatan Lingga Kabupaten Lingga Provinsi Kepulauan Riau yang berjarak kurang lebih 60 mil laut ke Desa Pekajang. Dari faktor jarak, maka Gugusan Pulau Tujuh yang diperebutkan dua provinsi itu, lebih dekat ke Kepulauan Bangka Belitung dari pada ke Kepulauan Riau.

Pulau Tujuh berdasarkan Surat perjanjian antara Kesultanan Riau dengan Pemerintahan VOC/Hindia Belanda sejak tahun 1748-1909 bernama Pulau Kudjangan. Bila dilihat dari atlas "Beschrigving van de straat Banca en Driven" tahun 1753 halaman $59^{6}$

\footnotetext{
${ }^{6}$ Namanya adalah Plo Taja yang letaknya berdekatan dengan plo Toupar. Gugusan pulau tersebut terletak di sebelah timur Varella (Pulau Berhala) dan berada pada koordinat ini dengan Bujur Timur serta $1^{0}$ LS dan berada pada koordinat $105^{\circ}-106^{\circ}$ Bujur timur serta $1^{0}$ LS (Tiderman, J., 1938:147). Letak koordinat ini sama dengan tata letak Karesidenan Palembang yaitu: pada $104^{\circ} 20^{\prime} 10^{\prime}$ ' $-106^{0} 35$ ' Bujur Timur (Wella, 1932, 1932:4). Pada saat itu belum di bentuk Karesidenan Bangka Belitung. Peta Karesidenan Palembang terletak pada Staatsblad no 244 Tahun 1916. Peta lain yang berkaitan dengan kawasan ini berasal dari Tahun 18191845, 1852, 1854, 1866 dan 1867 (Wellan, 1932: 6-7). Selain itu, Dokumen Pemerintahan Hindia Belanda Tahun 1941 tentang Residen Bangka Belitung tidak mencantumkan keberadaan gugusan Pulau Tujuh di dalam dokumennya. Nama-nama pulau dalam gugusan Pulau Tujuh yang tidak dicantumkannya itu kemungkinan karena tetap masuk dalam Karesidenan Palembang. Meskipun secara geografis letaknya lebih dekat dengan Pulau Bangka, 30 mil laut dari Belinyu.
}

Menurut Piere Yves Manguin (1884:20-21), peta Portugis yang dibuat pada Tahun 1513 (Peta 3). Pada peta ini, secara cermat menempatkan tiga lokasi jalur pintu masuk ke Palembang yang digambarkan sesuai benar dengan kondisi sekarang, misalnya untuk letaknya Tanjung Tapah (Diantapam), Air Banyuasin dan Sugihan. Dalam peta ini, nama-nama pulau dalam gugusan Pulau Tujuh tidak disebutkan, tetapi Pulau Berhala disebutkan dengan amat jelas lengkap dengan namanya, yaitu Pullo Bralla. Berdasarkan letak astronomis antara Pulau Berhala dengan Gugusan Pulau Tujuh hampir sejajar dan berada pada garis lintang yang sama, maka dapat diperkirakan bahwa pulau-pulau yang terletak di sebelah barat Pulau Bangka tersebut adalah gugusan Pulau Tujuh. Dalam peta Portugis lainnya, yang dibuat pada masa sesudahnya, gugusan pulau tujuh ini namanya Ilo Iotoau yang terletak di sebelah timur Ilo Tangor dan Ilo Varella, di sebelah Pulau Bangka.

Gugusan Pulau Tujuh, sebelum terbentuknya Pemerintahan Provinsi Kepulauan Bangka Belitung, termasuk pada wilayah Sumatera Selatan yang beribukota di Palembang. Peta tersebut di buat dan mengacu pada Peta Bangka Tahun 1955, skala 1:50, buatan the Army Map Service, Corps Of Engineers, US Army, Washingthon DC dan Netherland Hydrograpic Chart: 61 Tahun 1911.

Dalam Peta Kecamatan Belinyu, gugusan Pulau Tujuh secara kuantitatif jumlahnya lebih dari tujuh. Hal ini dikarenakan ada beberapa pulau yang ukurannya relatif besar dikelilingi oleh pulau-pulau kecil. Adapun nama pulau-pulau dalam Peta Kecamatan Belinyu, adalah sebagai berikut: Pulau Tokong Kembang, Pulau Kachangan, Pulau Chebia, Pulau Satu, Pulau Meranti, Pulau Lalang, Pulau Ju.

\section{b. Dari Sisi Yuridis}

Secara yuridis formal (dilihat dari hukum dan undang-undang yang ada), yang tercantum dalam Undang-Undang No. 27 Tahun 2000 tentang Pembentukan Provinsi Kepulauan Bangka Belitung. Baik secara defakto maupun de jure, gugusan Pulau tujuh dan Pulau Dua merupakan bagian dari wilayah Provinsi Kepulauan Bangka Belitung yang di perkuat dengan:

1) Instruksi Menteri Dalam Negeri Nomor: 5 Tahun 2000, tanggal 23 Agustus 2000 tentang Pemberian dan Inventarisasi nama-nama Geografis dan hasil Rakornas Wilayah Administrasi dan Perbatasan, agar setiap Kabupaten mendata ulang pulau-pulau yang berada di wilayah masing-masing yang disesuaikan dengan wilayah administrasi setelah hasil pemekaran;

2) Surat Menteri Dalam Negeri Republik Indonesia Nomor: 125.1/531/SJ pada Maret 
2006, tentang Percepatan Pendataan dan Penamaan Pulau di Indonesia;

3) Surat Keputusan Bupati Bangka Nomor: 188/45/281/1/2006 tentang Penetapan Daftar Pulau-Pulau di Wilayah Kabupaten Bangka;

4) Data pulau yang ada di Pemerintah Provinsi Kepulauan Bangka Belitung dan Hasil Dinas Hydro Oceanografi TNI AL Tahun 1987;

5) Surat Bupati Bangka Nomor: 180/1080/II/2002 tertanggal 24 mei 2002, tentang Pemberian Nama-Nama Geografi Pulau;

6) Hasil pendataan dan inventarisir Pulau-Pulau di Kabupaten Daerah Tingkat II oleh Provinsi Sumatera Selatan Tahun 1994/1955;

7) Daftar nama-nama penamaan unsur Geografis (Toponimi) Pulau hasil Pendataan dan Survey Departemen Kelautan dan Perikanan. Namanama Pulau yang ada di Provinsi Kepulauan Bangka Belitung termasuk Pulau Tujuh telah di kirim ke Menteri Dalam Negeri;

8) Rapat Koordinasi menyeluruh dari unsur-unsur Muspida Provinsi Kepulauan Bangka Belitung, Dinas dan Badan atau Kantor terkait;

9) Peta Wilayah Nomor: 60 dan Peta 360 (Dinas Hydro Oceanografi) dan Peta Lampiran Undang-Undang Republik Indonesia Nomor: 27 Tahun 2000, mengenai Batas Wilayah dan Titik Koordinat Wilayah Keberadaan Gugusan Pulau Tujuh;

10)Dalam Peta yang dikeluarkan Pemerintah Kolonial Belanda, Staadblad 1412 dan 1434 tahun 1922, yang menunjukan bahwa Gugusan Pulau Tujuh berada di perairan Laut Muntok dan Perairan Laut Belinyu, Kepulauan Bangka Belitung;

11) Peta Wilayah Provinsi Kepulauan Bangka Belitung berdasarkan Undang-Undang Republik Indonesia Nomor 27 Tahun 2000 tentang Pembentukan Provinsi Kepulauan Bangka Belitung.

\section{c. Dari Sisi Pemerintahan}

Dari sisi pengelolaan administrasi pemerintahan daerah setempat, Kabupaten Lingga telah melakukan upaya lebih dahulu seperti keberadaan sarana pendukung bidang pendidikan, kesehatan, transportasi dan pemerintahan. Namun dari sisi geografis dan hubungan ekonomi penduduk kepulauan tersebut, Gugusan Pulau Tujuh dengan Pulau Pekajang Cibia di dalamnya lebih dekat ke Provinsi Kepulauan Bangka Belitung. Adanya keinginan Pemerintah Provinsi Kepulauan Bangka Belitung untuk memiliki Pulau Tujuh sebagai batas luar wilayah, dapat dan menjadi bahan pertimbangan. Namun, lebih penting lagi adalah mempertimbangkan untuk mengembangkan daerah ini untuk meningkatkan kesejahteraan masyarakat secara luas.

Hal ini memang diakui oleh informan kunci yang ada di lapangan. Walaupun secara yuridis, jika dilihat dari Undang-undang Pemekaran Provinsi Kepulauan Bangka Belitung, yaitu: UU Nomor 27 Tahun 2000, wilayah/ kawasan Gugusan Pulau Tujuh memang dimasukkan di dalam UU ini, tapi pada kenyataannya, Desa Pekajang yang merupakan satu-satunya Desa di situ tetapi tidak diperhatikan oleh Provinsi ini. Informan kunci yang ada di Pangkal Pinang menyatakan bahwa Pemerintah Provinsi baru ini sibuk dengan penataan-penataan di ibukota provinsi, dan agak cenderung mengabaikan apa yang telah diperolehnya melalui pemekaran wilayahnya, yaitu: mengurusi wilayahnya yang di pinggiran, termasuk kawasan Gugusan Pulau Tujuh. Dan ketika, terjadi pemekaran Kabupaten Lingga Provinsi Kepulauan Riau yang mencakup juga gugusan Pulau Tujuh, mereka yang Bangka Belitung mulai "tersentak". Apalagi ketika pembangunan terus dilakukan di Desa Pekajang oleh Pemerintah Provinsi Kepulauan Riau, maka pihak Pemerintah Kepulauan Bangka Belitung mulai "gerah" dan pada akhirnya membentuk Tim Pengembalian Pulau Pekajang di Gugusan Pulau Tujuh.

\section{d. Dari Sisi Sosial Budaya}

Dari informasi kesejarahan lain, ditemukan juga oleh Pemerintah Provinsi Kepulauan Bangka Belitung, yaitu: adanya dokumen Pemerintahan Belanda Tahun 1941 tentang Residen Bangka Belitung yang tidak mencantumkan keberadaan Gugusan Pulau Tujuh di dalam dokumennya. Ada kemungkinan tidak dicantumkannya nama-nama pulau dalam Gugusan Pulau Tujuh, dikarenakan tetap masuk dalam Karesidenan Palembang. Meskipun secara geografis letaknya lebih dekat dengan Pulau Bangka, yaitu berjarak kurang lebih 30 mil laut dari Kecamatan Belinyu. Faktor geografis ini juga yang menjadi alassan bagi masyarakat nelayan di Pulau Bangka, terutama dari Kecamatan Belinyu, Sungailiat, Jebus dan Kecamatan Tobali yang secara historis pada musim-musim tertentu mencari ikan di Gugusan Pulau Tujuh. Dengan demikian tidak mengherankan jika masyarakat Bangka merasa bahwa Gugusan Pulau Tujuh merupakan hak tradisionalnya dan secara ekonomis menjadi bagian dari daerah tangkapan (cathment area) mereka.

Selain itu, berdasarkan sumber-sumber sejarah yang telah dipaparkan di atas dapat diketahui bahwa Gugusan Pulau Tujuh sudah tercantum dalam Peta Portugis Tahun 1513. Sementara dalam Peta Hindia Belanda telah dimuat pada Tahun 1753. Hal ini berbeda dengan Pulau Berhala yang ada didekatnya, nama Pulau Tujuh jarang dicantumkan dalam peta pelayaran internasional, nama-nama pulau dalam Gugusan Pulau Tujuh juga tidak pernah disinggung atau dicatat dalam laporan perjalanan. Hal ini 
kemungkinan karena peran pulau-pulau tersebut kurang menonjol secara ekonomis, yang ditandai dengan masih tiadanya penghuni sampai saat ini (kecuali Pulau Ciba). Dalam lalu lintas pelayaran, Gugusan Pulau Tujuh kurang berperan, terbukti dengan belum ditemukannya adanya bangkai karam di sekitar Gugusan Pulau Tujuh. Padahal jika diperhatikan, di sekitar Kepulauan Bangka Belitung telah ditemukan tidak kurang dari 18 titik bangkai kapal tenggelam.

Saat ini, di Gugusan Pulau Tujuh (selain Pulau Cibia) merupakan lokasi mencari ikan bagi masyarakat Bangka sehingga kawasan ini berperan sebagai penyangga ekonomi. Meski penangkapan ikan di wilayah ini dilakukan pada musim-musim tertentu saja. Oleh karena itu, perlu diupayakan untuk mengembangkan daerah ini, terutama secara ekonomis. Pengembangan daerah ini sebagai pengembangan sarang wallet atau daerah tujuan wisata bisa dikaji secara komperensif.

Karena jaraknya yang cukup dekat dengan Kecamatan Belinyu Kabupaten Bangka Induk, maka nelayan-nelayan dari Gugusan Pulau Tujuh setelah mencari ikan di kawasannya lebih memilih memasarkannya ke Belinyu yang jaraknya lebih dekat daripada memasarkannya di Kabupaten Lingga. Faktor jarak inilah, yang kemudian dimanfaatkan warga Desa Pekajang yang berada di kawasan Gugusan Pulau Tujuh untuk sarana jual beli, berobat, dan lain-lain menyangkut kebutuhan sehari-hari. Warga dan pihak Kecamatan Belinyu pun tidak memasalahkannya, yang penting saling menguntungkan ke dua belah pihak.

\section{Provinsi Kepulauan Riau}

\section{a. Dari Sisi Historis}

Dari sejarah cerita dan kepercayaan masyarakat secara turun temurun asal mula nama Pulau Pekajang sebetulnya bermuara dari sebuah "kajang" (sejenis tikar dari daun nipah yang dianyam sedemikian rupa untuk sebagai atap bagi perahu atau sampan) yang pada ketika itu jaman dahulu ketika orang hendak pulang pergi dari Pekajang atau Daik hanya dengan menggunakan perahu atau sampan hanya dengan menggunakan perahu atau sampan, karena perjalanannya menghabiskan waktu berhari-hari baru sampai maka mereka memasang kajang sebagai atapnya, yang lama kelamaan timbullah istilah apabila hendak ke pulau tersebut haruslah berkajang (sampan atau perahu yang menggunakan atap dari kajang) yang lama-kelamaan istilah tersebut dari berkajang menjadi pekajang).

Nama lain Pulau Pekajang adalah Pulau Cebia atau Pulau Tujuh. Nama Cebia berasal dari terdamparnya sebuah Kapal Belanda bernama Cebia di atas karang depan Pulau Pekajang dan oleh Belanda untuk menginggat pulau tersebut di beri nama Pulau Cebia (Cebia island), dan ketika Belanda membuat Peta mereka menyebut nama pulau tersebut dengan pulau-pulau tujuh karena pulau tersebut merupakan pulau-pulau yang berkelompok tujuh buah pulau.

Dari aspek historis kepemilikan Gugus Pulau

Tujuh dapat dilihat sebagai berikut:

1) Cerita rakyat jaman kerajaan Melayu Riouw Lingga yg berpusat Daik; daerah Pulau pekajang dan pulau-pulau disekelilingnya telah menjadi daerah taklukan kerajaan Melayu Lingga Riau dan pembinaan serta pengamanan penduduk menjadi tanggung jawab kerajaan Lingga.

2) Surat Perjanjian antara Kesultanan Riau dengan Pemerintahan VOC dan Hindia Belanda sejak tahun 1748-1909; terdapat nama Pulau Kudjangan, yang diidentifikasikan sebagai Pulau tujuh dalam wilayah Kerajaan Lingga Riau.

3) Perjanjian Kesultanan Riouw Lingga Lingga dengan Pemerintahan VOC (1787-1904), yg diterbitkan oleh Arsip Nasional RI 1970 hal. 118;

4) Pulau-pulau sebelah barat selat Sebojo yg belum di ketahui namanya \& tempatnya satu persatu adalah Pulau Saja (tiga Pulau), sekarang dikenal dengan nama pulau Sayak dan pulau kujangan (Tujuh Pulau) oleh pemerintah Belanda dimasukkan dalam wilayah kekuasaan Kerajaan Lingga Riau dan dipertegas oleh Peta Riouw-(Rijau) en Lingga Archipel dan peta Residentie Riouw En Onderhoorighedden Blad: 1 tahun 1922; Afedelling Toedjoh.

\section{b. Dari Sisi Yuridis}

Secara yuridis Pembentukan Kabupaten Lingga merupakan hasil pemekaran dari Provinsi Kepulauan Riau. Pembentukan ini secara "de jure" pada tanggal 18 Desember 2003 yang didasarkan oleh Undang-Undang Republik Indonesia Nomor 31 Tahun 2003, yang tercantum dalam Pasal 2,3,4 dan 5 (ayat 1 sampai dengan 3) dengan penjelasan sebagai berikut:

Pasal 2:

"Dengan Undang-Undang ini dibentuk Kabupaten Lingga di Provinsi Kepulauan Riau dan Negara Kesatuan Republik Indonesia”

\section{Pasal 3:}

"Kabupaten Lingga berasal dari sebagian wilayah Kepulauan Riau yang terdiri atas:

1) Kecamatan Senayang;

2) Kecamatan Lingga;

3) Kecamatan Lingga Utara;

4) Kecamatan Singkep;

5) Kecamatan Singkep Barat.

Pasal 4:

Dengan terbentuknya Kabupaten Lingga, sebagaimana dimaksud pada pasal 2 (dua), wilayah Kabupaten Riau dikurangi dengan 
wilayah Kabupaten Lingga sebagaimana dimaksud dengan Pasal 3 (tiga).

Pasal 5 ayat 1 (satu):

Kabupaten Lingga mempunyai batas wilayah:

a. Sebelah barat berbatasan dengan Kecamatan Galang Kota Batam dan Laut Cina Selatan;

b. Sebelah timur berbatasan dengan Laut Cina Selatan;

c. Sebelah selatan berbatasan dengan Laut Bangka dan Selat Berhala;

d. Sebelah barat berbatasan dengan laut Indragiri

\section{Pasal 5 ayat 2 (dua):}

Batas wilayah sebagaimana dimaksud dengan ayat 1 (satu) digambarkan dalam Peta Wilayah Administrasi yang merupakan bagian yang tak terpisahkan dari undang-undang ini.

\section{Pasal 5 ayat 3 (tiga):}

Penentuan batas wilayah Kabupaten Lingga secara pasti di lapangan sebagaimana dimaksud dengan ayat 1 (satu) ditetapkan Menteri Dalam Negeri.

Jika kita melihat Surat Keputusan Dewan Perwakilan Rakyat Daerah (DPRD) Riau Nomor 336/DPRD/2003 tanggal 5 Maret 2003 menyatakan bahwa:

1. Desa Pekajang berada di wilayah hukum Pemerintahan Kabupaten Riau dan tidak pernah menyerahkan Desa Pekajang kepada Pemerintah Provinsi Kepulauan Bangka Belitung;

2. Lampiran Undang-undang Republik Indonesia Nomor 31 Tahun 2003, tentang Pembentukan Kabupaten Lingga, dinyatakan bahwa Pulau Cibia masuk pula dalam wilayah Kabupaten Lingga.

Selain itu dari dokumen masa Pemerintahan Kolonial Belanda dapat di temukan yaitu: Staatblad Van Nederlandsch-Indie 1922 No.66, Binnelandsch Bestuur Benkolen, djambi, Banka En Onderhoorrigheden Riuow En Onderhoorigheden Bali En Lombok. Omvorming van eenige zelfstandigo afdeeling in de Buitengewesten tot onderafdeelingen met nieuwe vastelling der administratieve indeeling van genomde gewesten. Besluit van den Gouverneur General van nederlandsch-Indie van 2 Pebruari 1922 No. 34.

Staatblad Van Nederlandsch-Indie 1924 No.201, Binnelandsch Bestuur gezaghebbeers Schrijvers Huishuurvergoedingen Beloonigen Toelangen Eed Kleeding Reis En Verblijfkosten. Riau en Onderhoorigheden. Wijziging van de inrichting en van bestuurmiddelen in genoemd gewest. . Besluit van den Gouverneur - General van nederlandsch-Indie van 29 April 1924 No. 51.

\section{c. Dari Sisi Pemerintahan}

Batas wilayah Desa Pekajang meliputi:

1. Sebelah Utara : Tanjung Nyang Desa Teluk

2. Sebelah Timur : Kalimantan Selatan / Selat Karimata

3. Sebelah Selatan: Provinsi Kepulauan Bangka Belitung

4. Sebelah Barat : Provinsi Jambi

Desa Pekajang terdiri dari 7 (tujuh) buah pulau yaitu:

1. Pulau Pekajang Kecil/Cebia (dihuni)

2. Pulau Pekajang Besar (tidak dihuni)

3. Pulau Penyaman (tidak dihuni)

4. Pulau Pasir Keliling (tidak dihuni)

5. Pulau Tokong Kembung (tidak dihuni)

6. Pulau Tokong Kembung (tidak dihuni)

7. Pulau Lalang (tidak dihuni)

Dari 7 (tujuh) pulau tersebut hanya 1 (satu) buah pulau yang dihuni yaitu Pulau Pekajang Kecil (Cebia) dengan luas keseluruhan kurang lebih $1756 \mathrm{~km}^{2}$.

Pada awal Kemerdekaan Republik Indonesia, Desa Pekajang merupakan desa definitif yang berada dalam Kecamatan Lingga dikenal dengan 'Kebatenan' dipimpin oleh seorang Kebatenan antara lain:

Kepala Kampung:

1. Baten Encik Idris' (1945 sampai dengan 1 Desember 1953) Pekajang;

2. Dul Ali (1 Desember 1953 sampai dengan 1 November 1964)

3. Dul Said (1 November sampai dengan 16 Juni 1975)

Kepala Desa (mulai tahun 1975):

1. Bujang Ayub (16 Juni 1975 - 25 Februari 1999)

2. Pjs Amin Komeng (25 Februari 1999 - 11 juli 2003)

3. Kamis (11 juli 2003 s/d 1 Desember 2003 - 1 Desember 2005)

4. Pjs Siman (1 Desember 2003 - sekarang)

Kegiatan Pemerintahan dilaksanakan sejak awal kemerdekaan dalam bentuk pelayanan administrasi pemerintahan yg dilayani oleh aparat Pemerintahan Kecamatan Lingga Kabupaten Kepulauan Riau/ Kabupaten Lingga, seperti:

1. KK, KTP \& Akta kelahiran penduduk warga Desa Pekajang

2. Kartu Perorangan masyarakat Desa Pekajang No.1/XII/1982

3. SK Camat Lingga No. 003/KTPS/IX/1979 tanggal 6 September tentang Pengangkatan Juru Tulis dan Tiga Pamong Desa lainnya di setiap kepenghuluan dalam wilayah Kecamatan Lingga.

4. Surat Keputusan Kantor Urusan Agama (KUA) Kec. Lingga Kab. Riau No. K.10/D6/1.C/475/1985 tanggal 25 Maret 1985 tentang Data Masjid di Desa/Kelurahan dalam Kec. Lingga, salah satunya Desa Pekajang 
5. Daftar tanda terima biaya Pemilu tahun 1987 untuk Panitia Pendaftaran Pemilih (Pantarlih) Desa Pekajang

6. Daftar Usulan Rencana Proyek Desa Program Bantuan Pembangunan Desa tahun 1989/1990 untuk Desa Pekajang Kec. Lingga Kab. Kep. Riau

7. SK Camat Lingga No. 08/KTPS/V/1990 Tanggal 01 Mei 1990 tentang Pemberhentian dan Penganggkatan Kepala Satgas Hansip Desa/Kelurahan Desa Pekajang

8. SK Bupati Kepala Daerah Tingkat II Kep. Riau No. KPTS. 115/VII/1991 tanggal 17 Juli 1991 tentang Penunjukan Petugas/Pungut Pajak Bumi dan Bangunan Bidang Perkotaan dan Pedesaan Dalam Wilayah Kab. Daerah Tk. II Kep. Riau, termasuk dalamnya Desa Pekajang.

9. SK Desa Pekajang Kec. Lingga Kab. Daerah Tk.II Kep. Riau No. KPTS.03/VII/1998 tanggal 13 Juli 1998 tentang Anggaran Penerimaan Dan Pengeluaran Keuangan Desa (APPKD) Desa Pekajang.

10. Surat Pernyataan No. 001/PKJ/25-2-2003 Tentang Pernyataan warga Desa Pekajang bahwa tidak mau bergabung dengan Bangka Belitung

11. Surat Pernyataan Kolektif masyarakat Desa Pekajang tanggal 2 Mei 2006 tentang status keberadaaan Desa Pekajang sejak jaman Kerajaan Kesultanan Riouw Lingga sampai saat ini merupakan bagian dari kecamatan Lingga Kab. Kep. Riau/Kab. Lingga

12. Surat pernyataan dari Said Ahmad pensiunan Guru SD Kec. Lingga umur 89 tahun dan Abdul Gani pensiunan Kantor Camat Lingga Umur 80 tahun yang menyatakan bahwa "kami mengetahui benar tentang keberadaan Pulau/Desa Pekajang dari jaman Sultan Lingga, jaman Belanda, jaman Jepang, dan jaman setelah Indonesia Merdeka sampai dengan saat ini berada diwilayah Kecamatan Lingga Kab. Kep. Riau/Kab. Lingga.

13. Surat Keputusan Dewan Pemerintahan Daerah Sementara Kab. Kep. Riau No. 90/3/Dprsk Tanggal 07 Desember 1953 tentang pengangkatan Dul Ali menjadi Wakil Penghulu Pekajang Kec. Lingga di Pekajang.

14. Surat keputusan Wedana Lingga No. 5/B27/1964; tanggal 11 November 1964 tentang pengangkatan Dol Sjaid sebagai Kepala Kampung Pekajang.

15. Surat Keputusan Camat Lingga No, 1054/B35/75 tanggal 16 Juni 1975 tentang Penunjukan sementara untuk menjalankan tugas Pekerjaan Kepala Kampung di Pekajang.

16. Surat Keputusan Bupati Kepala Daerah Tingkat II Kep. Riua, No. SK..31/II/99; tanggal 25 Pebruari 1999 tentang Pemberhentian dan Pengangkatan Pejabat Sementara Kepala Desa Pekajang Kec. Lingga.
17. Surat Keputusan Bupati Kep. Riau No. 267/VII/20003; tanggal 11 Juli 2003 tentang Pemberhentian dan pengangkatan Kepala Desa Pekajang, Kerandin, kelombok, Keton dan Bukit Harapan, Kec. Lingga Kab. Kep. Riau.

18. Surat keputusan Bupati kep. Riau No. 171/KTPS/XII/2005; tanggal 01 Desember 2005 tentang Pemberhentian dan Pengangkatan Pejabat Sementara Kepala Desa Pekajang Kec. Lingga Kab. Lingga.

Salah satu desa yang masuk dalam wilayah Kecamatan Lingga Kabupaten Lingga adalah Desa Pekajang yang terdiri dari 1 (satu) dusun 1 (satu) Rukun Warga (RW) dan 2 (dua) Rukun Tetangga (RT) dengan populasi jumlah penduduk sampai dengan bulan Maret 2006 sebanyak 339 jiwa dari 89 Kepala Keluarga (KK).

\section{d. Dari Sisi Sosial Budaya}

Pulau Pekajang/Kujangan/ di jaman Sultan dipimpin oleh kepala Suku yang bernama Encek Diah yang mendapat anugerah Sultan berupa sebilah Pedang berkepala Naga dan sepasang Tombak Berambu yang saat ini masih dipegang oleh keturunan Encek daerah tersebut. Secara geografis Desa Pekajang sangat strategis dan potensial menjadi tempat wisata bahari karena memiliki pulau-pulau yang sangat indah dan laut yang dalam sehingga sangat kaya dengan sumber daya alamnya seperti bahan tambang antara lain batu granit, pasir kuarsa, bijih timah dan perikanan laut serta pantai menawan tempat penyu bertelur dan terdapat gua batu di Pulau Kembung tempat menghasil sarang burung walet yang dikelola Lembaga Pemberdayaan Masyarakat setempat secara tradisonil. Mata pencarian penduduk Desa Pekajang adalah nelayan yang hasil tangkapannya di jual ke wilayah ibukota Kabupaten Lingga.

Jarak Desa Pekajang dengan ibu Kota Kecamatan Lingga dan Ibu Kota Kabupaten Lingga \pm 70 mil dengan melalui dermaga Tanjung Buton Kecamatan Lingga dengan menggunakan speedboat lama perjalanan selama 2,5 jam.

\section{Analisa}

\section{a. Gugusan Pulau Tujuh yang Dipandang Pemerintah Provinsi dan Masyarakat Kepulauan Bangka Belitung}

Pulau Tujuh merupakan gugusan pulau yang terletak di sebelah barat Pulau Bangka dan berjarak 30 mil laut dari Belinyu, tempat masyarakat Pulau Pekajang Cibia memenuhi kebutuhan sehari-hari. Meskipun demikian, secara administratif dan yuridis masuk wilayah Kabupaten Lingga Provinsi Kepulauan Riau, seperti tertuang dalam UU Nomor 31 Tahun 2003 tentang Pembentukan Kabupaten Lingga Provinsi Kepulauan Riau. Padahal, dalam Peta Lampiran UU Nomor 27 Tahun 2000, tentang Pembentukan Provinsi Kepulauan Bangka Belitung, Pulau 
Pekajang Cibia termasuk dalam wilayahnya. Dengan terbitnya dua UU yang dikeluarkan Pemerintah Pusat tersebut berakibat pada munculnya masalah perbatasan di antara Provinsi Kepulauan Riau (Pemkab. Lingga) dengan Provinsi Kepulauan Bangka Belitung (Pemkab. Bangka Induk).

Dalam kasus dan permasalahan kepemilikan Gugusan Pulau Tujuh yang diperebutkan antara Provinsi Kepulauan Bangka Belitung dengan Provinsi Kepulauan Riau (yang masuk dalam wilayah Kabupaten Lingga) diawali dari adanya Lampiran UU Nomor 27 Tahun 2000 tentang Pembentukan Provinsi Kepulauan Belitung, bahwa Gugusan Pulau Tujuh (termasuk Pulau Pekajang Cibia) termasuk dalam provinsi Kepulauan Bangka Belitung. Sementara itu, dalam Lampiran UU Nomor 31 tahun 2003 tentang Pembentukan Kabupaten Lingga Provinsi Kepulauan Riau, Pulau Cibia (Pekajang Cibia) yang menjadi salah satu dari Gugusan Pulau Tujuh dimasukan ke dalam wilayah Kabupaten Lingga. Kabupaten Lingga ini sebelumnya merupakan Kecamatan, dan masuk ke dalam wilayah hukum Pemerintah Kabupaten Kepulauan Riau Provinsi Riau (sebelum terjadinya pemekaran).

Terlepas dari permasalahan tentang batas wilayah antara kedua provinsi, yang jelas dalam Peta Belinyu (skala 1: 250.000), gugusan Pulau Tujuh sebelum terbentuknya Provinsi Kepulauan Bangka Belitung, masuk wilayah Sumatra Selatan. Peta ini dibuat dengan mengacu dari beberapa Peta, antara lain: a) Peta Bangka tahun 1955 (skala 1: 50.000), buatan The Army Map Service, Corps of Engineers, U.S. Army, Washington D.C; Peta Sumatra (skala 1: 250.000), buatan Directorate of Military tahun 1945, dan Netherlands Hydrographic Chart 61 tahun 1911.

Dalam Peta Belinyu tersebut, gugusan Pulau Tujuh secara kuantitatif jumlahnya lebih dari tujuh, karena beberapa pulau yang ukurannya relative besar dikelilingi oleh beberapa pulau kecil. Adapun nama pulau dalam Peta Belinyu adalah: Pulau Tokongkembang, Kachangang, Chebia, Satu, Meranti, Lalang, dan Pulau Ju. Sementara menurut Pemprov. Kepulauan Bangka Belitung, ketujuh pulau tersebut adalah Pulau Pekajang Cibia, Pekajang Besar, Pasirkeling, Palang, Penyaman, Tokong Yu, dan Pulau Tekongkembang. Pulau-pulau tersebut mayoritas tanpa penghuni, kecuali Pulau Pekajang Cibia. Pulau Tekongkembang telah dimanfaatkan sebagai lokasi sarang burung wallet.

Secara historis sejak jaman Belanda, dikatakan bahwa Pulau Tujuh masuk wilayah Riau. Pernyataan ini dilengkapi dengan informasi tentang adanya Surat Perjanjian antara Kesultanan Riau dengan Pemerintahan VOC dan Hindia Belanda sejak tahun 1748-1909, terdapat nama Pulau Kudjangan, yang kemudian diidentifikasikan sebagai Pulau Tujuh dalam wilayah Kerajaan Lingga Riau. Pada Peta Sumatra tahun 1892, gugusan pulau di antara Pulau Lingga dan Pulau Bangka tidak tergambarkan. Namun demikian, sampai tahun 1910, Pemerintahan Hindia Belanda masih mengakui kedaulatan Kerajaan Lingga dan menganggapnya sebagai "negara asing" (Resink, 1987:28). Oleh karena itu, Pemerintahan Hindia Belanda memberlakukan hukum internasional yang menyangkut urusan pidana maupun perdata, termasuk di dalamnya kontrak perdagangan (Resink, 1987: 28). Bahkan Pemerintahan Hindia Belanda waktu itu menganggap bahwa sejumlah kerajaan yang ada di Indonesia (termasuk Siak, Riau, Lingga) sebagai Etats patrimonies (Negara warisan leluhur) tulen, meskipun mereka hidup di dalam suasana pengaruh budaya Belanda (Resink, 1987:29).

Pulau tujuh berdasarkan Surat Perjanjian antara Kesultanan Riau dengan Pemerintahan VOC dan Hindia Belanda sejak tahun 1748-1909 bernama Pulau Kudjangan, maka berdasarkan Atlas "Besschrijving van de straat Banca en Driven" tahun1753 halaman 59 namannya adalah Plo Taja yang letaknya berdekatan dengan Plo Toupar (?). Gugusan pulau tersebut terletak di sebelah timur Varella (Pulau Berhala) dan berada pada koordinat 105'-106' Bujur Timur serta 1' Lintang Selatan (Tideman, J., 1938:147). Letak koordinat ini sama dengan terletaknya Karesidenan Palembang yang berada pada 104*20'10',-106*35' Bujur Timur (Wellan, 1932:4). Pada saat itu belum terbentuk Karesidenan Bangka Belitung. Peta Karesidenan Palembang terdapat dalam staatsblad Nomor 244 tahun 1916. Peta lain yang berkaitan dengan kawasan ini berasal dari tahun 1819-1845, 1852, 1854, 1866, dan 1867 (Wellan, 1932:6-7). Koordinat Karesidenan Palembang di atas tidak jauh berbeda dengan letak koordinat Pulau Pekajang (Gugusan Pulau Tujuh) pada lampiran Peta Bangka Belitung berdasarkan UU Nomor 27 Tahun 2000, yaitu: 105*-106* Bujur Timur.

Informasi historis lainnya, dikemukakan oleh Pemerintah Provinsi Kepulauan Bangka Belitung, yaitu: dokumen Pemerintahan Belanda tahun 1941 tentang Residen Bangka Belitung yang tidak mencantumkan keberadaan gugusan Pulau Tujuh di dalam dokumennya. Tidak dicantumkannya nama-nama pulau dalam gugusan Pulau Tujuh kemungkinan karena tetap masuk wilayah Karesidenan Palembang. Meskipun secara geografis letaknya lebih dekat dengan Pulau Bangka, 30 mil laut dari Belinyu. Faktor geografis inilah yang kemungkinan menjadi alasan bagi masyarakat nelayan di Pulau Bangka, terutama dari Kecamatan Belinyu, Kecamatan Sungailiat, Kecamatan Jebus, dan Kecamatan Toboali secara historis pada musim tertentu mencari ikan di Pulau Tujuh. Dengan demikian tidak mengherankan jika 
masyarakat Bangka merasa bahwa gugusan Pulau Tujuh merupakan hak tradisionalnya dan secara ekonomis menjadi bagian dari daerah tangkapan (cathment area) mereka.

Menurut Piere Yves Manguin (1984: 20-21), Peta Portugis yang dibuat pada tahun 1513, merupakan peta dengan kecermatan yang luar biasa tinggi untuk ukuran waktu itu, yang tidak dapat diimbangi oleh Peta Portugis abad ke enam belas lainnya. Dalam peta ini secara cermat menempatkan tiga lokasi jalur pintu masuk ke Palembang yang digambarkan sesuai dengan kondisi sekarang. Misalnya, untuk melihat letak Tanjung Tapah (Diantapam), Air Banyuasin, dan Sugihan. Dalam peta ini, nama-nama pulau dalam gugusan Pulau Tujuh tidak disebutkan, tetapi Pulau Berhala disebutkan dengan amat jelas lengkap dengan namanya, yaitu: Pulau Bralla.

Berdasarkan letak astronomi, antara Pulau Berhala dengan gugusan Pulau tujuh hampir sejajar dan berada pada garis lintang yang sama, maka dapat diperkirakan bahwa pulau-pulau yang terletak di sebelah barat Pulau Bangka tersebut adalah gugusan Pulau Tujuh. Dalam Peta Portugis lainnya yang dibuat pada waktu kemudian, gugusan Pulau Tujuh ini namanya Ilo Ioutoau yang terletak di sebelah timur Ilo Tangpor dan Ilo Varella, di sebelah barat Pulau Bangka.

Berdasarkan sumber-sumber sejarah yang telah disebutkan, dapat diketahui bahwa gugusan Pulau Tujuh sudah tercantum dalam Peta Portugis tahun 1513. Sementara dalam Peta Belanda baru dimuat pada tahun 1753. Berbeda dengan Pulau Berhala yang ada di dekatnya, nama Pulau Tujuh jarang dicantumkan dalam peta pelayaran internasional. Begitupun dalam sumber-sumber berita asing, baik Arab, Cina, maupun Portugis, nama-nama pulau dalam gugusan Pulau Tujuh juga tidak pernah disinggung atau dicatat dalam laporan perjalanan. Hal ini kemungkinan karena memang peran pulau-pulau ini kurang menonjol secara ekonomis, yang ditandai dengan masih tiadanya penghuni sampai saat ini (kecuali Pulau Cibia). Dalam lalu lintas pelayaran pun gugusan Pulau Tujuh kurang berperan, terbukti dengan belum ditemukannya adanya bangkai kapal karam di sekitar gugusan Pulau Tujuh.

Jika dilihat dari sisi geografis dan hubungan ekonomi penduduk kepulauan tersebut, gugusan Pulau Tujuh dengan Pulau Pekajang Cibia di dalamnya lebih dekat ke Provinsi Kepulauan Bangka Belitung (30 mil laut dari Kecamatan Belinyu Kabupaten Bangka). Sementara jika ditarik ke arah wilayah Provinsi Kepulauan Riau berjarak kurang lebih 60 mil laut dari Kecamatan Lingga Provinsi Kepulauan Riau. Namun secara de facto, adanya perkampungan penduduk dengan sebuah desa di Pulau Pekajang Cibia secara administrasi telah menginduk kepada Kecamatan Lingga Kabupaten Lingga.
Secara historis perairan Gugusan Pulau Tujuh secara tradisional merupakan wilayah penangkapan ikan nelayan provinsi Kepulauan Bangka Belitung, dan penduduk desa Pekajang Cibia secara ekonomi lebih banyak berhubungan dengan Kecamatan Belinyu Kabupaten Bangka yang hanya berjarak kurang lebih 30 mil laut daripada jarak Kecamatan Lingga Kabupaten Lingga yang berjarak lebih kurang 60 mil laut. Namun dari sisi pengelolaan daerah setempat Kabupaten Lingga telah melakukan upaya lebih dahulu seperti keberadaan beberapa sarana pendukung bidang pendidikan, kesehatan, transportasi dan pemerintahan. Dari walaupun tempuh/kedekatan wilayah lebih dekat dengan Kabupaten Bangka Provinsi Bangka Belitung, namun pada kenyataan penduduk Pulau Pekajang Cibia adalah warga Kabupaten Lingga.

Dari apa yang yang diupayakan oleh Pemerintah Provinsi Kepulauan Bangka Belitung sebagaimana dalam Nota Dinas tanggal 14 April 2005 perihal Laporan Hasil Rapat Koordinasi mengenai status Pulau Tujuh, perlu ditindaklanjuti secara sistematis dan terencana antara lain:

1. Secara sistematis mengingat Kementerian Dalam Negeri telah menargetkan penyelesaian penegasan dan penetapan batas daerah paling lambat diselesaikan 2014. Untik itu perlu upaya-upaya pendekatan-pendekatan formal maupun secara informal kepada tim penyelesaian Kementerian Dalam Negeri.

2. Secara terencana upaya pemulihan Gugusan Pulau tujuh sesuai dengan Lampiran Peta pada UU Nomor 27 tahun 2000 tentang Pembentukan Provinsi kepulauan Bangka Belitung yang 3 tahun lebih awal bila dibandingkan dengan lampiran UU Nomor 31 tahun 2003 tentang Pembentukan Kabupaten Lingga.

3. Upaya sistematis dan terencana dalam penyelesaian Gugusan Pulau Tujuh harus dilakukan secara maksimal karena target waktu penyelesaian oleh Kementerian Dalam Negeri kurang dari 4 tahun. Untuk itu perlu kerjasama di semua tingkatan masyarakat dan pemerintahan Provinsi kepulauan Bangka Belitung guna penyelesaian masalah tersebut dengan hasil yaitu Gugusan Pulau Tujuh tetap sesuai dengan Peta Lampiran UU Nomor 27 tahun 2000. Namun jika tidak, sebagian Gugusan pulau Tujuh tetap menjadi wilayah Provinsi Kepulauan Bangka Belitung. Dengan demikian titik terluar Provinsi Kepulauan Bangka Belitung dapat ditentukan.

Saat ini, kepemilikan Gugusan Pulau Tujuh dipertanyakan secara serius oleh pihak Pemerintah Provinsi Kepulauan Bangka Belitung, pada saat kunjungan anggota Komisi II Dewan Perwakilan Rakyat Republik Indonesia di Bangka Belitung tanggal 10 Maret 2011. Gubernur pada saat itu, 
menyampaikan permasalahan sengketa batas antara Provinsi Kepulauan Bangka Belitung dengan Provinsi Kepulauan Riau mengenai gugusan Pulau Tujuh belum tuntas. Pulau Tujuh menurut UU Nomor 27 Tahun 2000 masuk wilayah Provinsi Kepulauan Bangka Belitung. Sementara itu menurut UU Nomor 25 Tahun 2002 Tentang pembentukan Provinsi Kepulauan Riau dan UU Nomor 5 Tahun 2003 tentang pembentukan Kabupaten Lingga Provinsi Kepuluan Riau, Pulau Tujuh dimasukkan ke dalam wilayah tersebut sehingga UU tersebut overlap.

\section{b. Gugusan Pulau Tujuh yang Dipandang Pemerintah Provinsi dan Masyarakat Kepulauan Riau}

Dari sumber-sumber yang diperoleh oleh penulis pada waktu penelitian ke lapangan yaitu adanya pertemuan dengan Ketua dan anggota Komisi I DPRD Kepulauan Riau di Ruang Sidang DPRD (Tanjung Pinang, bulan Mei 2011), terekam antara lain:

1. Nasution (anggota Komisi I) menyatakan bahwa: “....tidak berdasar Pekajang dimasukkan kedalam wilayah Provinsi Kepulauan Bangka Belitung jika hanya faktor kedekatan wilayah, bukan fakta-fakta..."

2. Sukri Fahrial (Ketua Komisi I) menyatakan bahwa: “...sebelum pemekaran kedua wilayah, Pulau Pekajang masuk Provinsi Riau dan tidak pernah bersengketa dengan Provinsi Sumatera Selatan yang waktu itu wilayahnya sampai Bangka Belitung.....dan "berharap Menteri Dalam Negeri menyelesaikan secara arif tanpa menimbulkan masalah di kemudian hari"...."jangan sampai memutuskan sesuatu yang menjadi masalah lebih besar"..

3. Iskandarsyah (Wakil Ketua Komisi I); “...Dalam UU pembentukan Kabupaten Lingga juga sudah jelas Pulau Pekajang masuk Kecamatan Lingga Kabupaten Lingga...dan..."kebijakan pusat hendaknya berdasarkan fakta bukan atas dasar kepentingan”dan "menyarankan agar pemerintah pusat segera menyelesaikan statu Pulau Berhala di Lingga yang kini masih dipersengketakan Pemerintah Provinsi Kepulauan Riau dan Pemerintah Provinsi Jambi..."

4. Misbardi (Kepala Bagian Pemerintahan Umum Biro Pemerintah Provinsi Kepulauan Riau) menyatakan bahwa: “...Pulau Pekajang jelas masuk wilayah Provinsi Kepulauan Riau seperti tercatat di "Staatblad van Nedherlandsch-Indie" atau Lembaran Negara Hindia Belanda tahun 1924 Nomor 201 ".... "sejak tahun 1954 Desa Pekajang juga tercatat di Departemen Dalam Negeri sebagai Desa Definitif yang masuk dalam Kabupaten
Kepulauan Riau, Provinsi Riau sebelum pemekaran..."

5. Lis Darmansyah (anggota Komisi I yang merangkap sebagai Wakil Ketua DPRD Provinsi Kepulauan Riau) menyatakan bahwa: “...Pemerintah Pusat tidak harus membahas masalah kepemilikan Pulau Pekajang karena sudah jelas...."

\section{c. Jalan Keluar Penyelesaian Masalah Sengketa Gugus Pulau Tujuh}

Sengketa kepemilikan Pulau Pekajang antara Provinsi Kepulauan Riau dengan Provinsi Kepulauan Bangka Belitung sebaiknya secara bijak dapat diselesaikan oleh Pemerintah Pusat dengan segera dan tidak menafikan keinginan masyarakat yang tinggal di pulau tersebut. Keinginan masyarakat di Pulau Pekajang tersebut harus digali sebenar-benarnya, apakah mereka ingin bergabung dengan warga Kepri atau menjadi warga Babel.

Penyelesaian sengketa Pulau Pekajang yang segera dilakukan sesuai keinginan masyarakat setempat, sesuai dengan pakar politik dari Kepri. Penyelesaian harus tidak perlu berlarut-larut. Pemerintah perlu mengutamakan keinginan masyarakat, kata pakar politik, Zamzami A Karim, yang juga Ketua Sekolah Tinggi Ilmu Sosial dan Ilmu Politik Tanjungpinang, Kepulauan Riau.

"Pertimbangan yang paling utama adalah aspirasi atau keinginan masyarakat di pulau itu, apakah ingin menjadi warga Kepulauan Riau, ataupun menjadi warga Bangka Belitung. Karena Pemerintah memiliki tanggung jawab terhadap masyarakat, terutama dalam memberikan rasa aman dan mensejahterakan kehidupan mereka," ungkapnya.

Walaupun aspirasi masyarakat warga setempat yaitu warga Desa Pekajang pada tahun 2003 yang tidak ingin bergabung dengan Bangka Belitung. Akan tetapi dengan kurun waktu hampir 10 (sepuluh) tahun perlu ditanyakan kembali kepada mereka. Apakah mereka ingin tetap di bawah Pemerintah Provinsi Kepulauan Riau, ataukah mereka ingin bergabung dengan Pemerintah Provinsi Kepulauan Bangka Belitung. Cara seperti ini barangkali merupakan solusi yang cukup tepat untuk dilakukan. Hanya saja pelaksanaannya tentu pihak Pemerintah yang akan menentukan yang mana, tanpa harus didikte oleh Daerah-daerah yang bersengketa.

Perebutan suatu pulau yang diperebutkan kepemilikannya oleh daerah, bukan saja menghabiskan anggaran daerah yang cukup besar, dan juga menguras tenaga dan waktu Pemerintah. Pemerintah Provinsi yang memperebutkannya guna kepentingan batas wilayah kekuasaan dan adanya sinyalemen potensi yang cukup besar yang terkandung di dalam pulau itu. Akan tetapi, hal ini perlu dikaji lebih mendalam lagi. Adanya 
perebutan Pulau Pekajang oleh ke dua provinsi tersebut, sebenarnya tidak perlu harus berlarutlarut. Hal ini dikarenakan ke dua pulau itu masih berada di wilayah Indonesia. Hal yang penting harus dijaga adalah Pemerintah baik Pusat maupun Daerah harus dapat meningkatkan kesejahteraan masyarakat yang tinggal di pulau terpencil itu. Klaim terhadap suatu pulau sudah seharusnya dalam bentuk perhatian yang lebih besar terhadap masyarakatnya yang selama ini tidak diperhatikan dan diabaikan oleh Pemerintah.

Sengketa Pulau Pekajang harus dapat diselesaikan oleh Pemerintah secepatnya. Pemerintah harus mengetahui keinginan masyarakat Pulau Pekajang tersebut. Kajian sejarah, kependudukan, kebudayaan, hukum dan bidang lainnya paling tidak digunakan untuk mendukung penetapan status pulau tersebut. Hal ini dikarenakan selama ini masing-masing provinsi yang memperebutkan pulau tersebut memiliki dasar dan alasan yang kuat. Dan yang paling penting, aspirasi masyarakat adalah faktor utama dalam menentukan status keberadaan pulau tersebut.

Keinginan masyarakat Pulau Pekajang akan merasa nyaman menjadi warga Kepulauan Riau, maka Pemerintah harus dapat merealisasikannya. Begitupun sebaliknya, Pemerintah juga harus mengikuti keinginan masyarakat dari Pulau Pekajang, apabila mereka ingin bergabung dengan warga Kepulauan Bangka Belitung. Harapan dan keinginan dari warga masyarakat Pulau Pekajang sebenarnya ke arah kesejahteraan masyarakat yang tinggal di Pulau itu agar lebih diperhatikan oleh Pemerintah, karena mereka di mana pun bergabung masih di wilayah naungan NKRI.

\section{SIMPULAN}

Sengketa kepemilikan Pulau Pekajang atau nama lain Gugus Pulau Tujuh antara Provinsi Kepulauan Riau dengan Provinsi Kepulauan Bangka Belitung yang sudah cukup berlarut-larut harus segera dapat diselesaikan oleh Pemerintah dengan bijak. Dengan bijak juga diartikan dengan tidak menafikan keinginan masyarakat yang tinggal di pulau tersebut. Keinginan dari masyarakat di kawasan tersebut harus digali sebenar-benarnya, agar keinginan mereka ingin bergabung dengan salah satu pihak, memang betulbetul dapat diapresiasi oleh Pemerintah.

\section{Rekomendasi}

Sebaiknya pihak Pemerintah (dalam hal ini pihak Kementerian Dalam Negeri) untuk segera menyelesaikan masalah sengketa segmen batas laut pada gugusan Pulau Tujuh yang melibatkan pihak Pemerintah Provinsi Kepulauan Bangka Belitung dengan Pemerintah Provinsi Kepulauan Riau yang mengacu pada empat pendekatan, yaitu:

1. Sisi Historis;
2. Sisi Yuridis;

3. Sisi Pemerintahan; dan

4. Sisi Sosial Budaya.

\section{DAFTAR PUSTAKA}

Buku:

Kenny, Anthony (ed). 1984. History of Western Philosophy, Oxford: Oxford University Press. Manguin, Piere Yves

Piliang, Indra J, dkk. 2003. Otonomi Daerah Evaluasi dan Proyeksi. Jakarta: Yayasan Harkat Bangsa

Pratchett, Lawrence. 2004. Local Authonomy, Local Democracy, and the New Localism Pye, Lucien W. \& Sydney. 1972. Political Culture and Political Development

Randall, John Herman, Jr, 1976, The Making of Modern Mind, New York: Colombia University Press

Ratnawati, Tri. 2006. Potret Pemerintahan Lokal di Indonesia di Masa Perubahan: Otonomi Daerah 2000-2005. Yogyakarta: Pustaka Pelajar

\section{Peraturan Perundang-Undangan:}

Atlas "Beschrigiving van de straat Banca en Driven", Tahun 1753.

Dokumen Maritim Nasional Departemen Kelautan dan Perikanan, Tahun 2004

Instruksi Menteri Dalam Negeri Nomor 5 Tahun 2000 Tentang Pemberian dan Inventarisasi Nama-nama Geografis

Laporan Pertanggungan Jawab Gubernur Kepulauan Bangka Belitung Tahun 2003

Peraturan Menteri Dalam Negeri Nomor 1 Tahun 2006 Tentang Pedoman Penegasan Batas Daerah

Peraturan Menteri Dalam Negeri Nomor 20 Tahun 2011 Tentang Pedoman Penelitian Dan Pengembangan Di Lingkungan Kementerian Dalam Negeri Dan Pemerintah Daerah

Peta Hindia Belanda, Tahun 1753.

Peta Portugis, Tahun 1513.

Sensus Ekonomi Nasional Tahun 2006

Sensus Penduduk Tahun 2002.

Staadblad 1412 dan 1434 Pemerintah Kolonial Hindia Belanda Tahun 1922

Undang-Undang No.32 Tahun 2004 Tentang Pemerintahan Daerah

Undang-Undang Nomor 17 Tahun 1985 Tentang Perairan Nusantara dan Wilayah ZEE

Undang-Undang Nomor 22 Tahun 1999 Tentang Pemerintahan Daerah

Undang-Undang Nomor 25 Tahun 2002 Tentang Pembentukan Provinsi Kepulauan Riau

Undang-Undang Nomor 27 Tahun 2000 Tentang Pembentukan Provinsi Kepulauan Bangka Belitung dan Peta Lampiran Tentang Batas Wilayah dan Titik Koordinat Wilayah Keberadaan Gugusan Pulau Tujuh

Undang-Undang Nomor 31 Tahun 2003 Tentang Pembentukan Kabupaten Lingga Kepri

Media Massa:

Harian Kompas, terbit 25 Juli 2003 
Http://adisanjaya24blogspot.com/2010/09/geopolitikindonesia-wawasan-nusantara.html

Majalah Berita Mingguan Tempo 18 April 2001 


\section{Biodata Penulis}

\begin{abstract}
Abdul Halik
Lahir di Kabupaten Bantaeng, Sulawesi Selatan,tanggal 5 Desember 1966. Lulus D III APDN di Ujung Pandang tahun 1988, S1 IIP Jurusan Politik Jakarta 1994, S2 Kebijakan Publik MAP UGM Yogyakarta 1997, S3 Jurusan Penelitian dan Evaluasi Pendidikan UNJ Jakarta tahun 2008. Dosen luar biasa dibeberapa Perguruan Tinggi Swasta di Jakarta tahun 1999 sampai dengan sekarang. Pangkat Pembina (IV/a), staf pada Puslitbang Pemdes \& Pemnas BPP Kemendagri, Calon Pejabat Fungsional Peneliti.
\end{abstract}

\section{Asrori}

Lahir di Kudus, Jawa Tengah pada 7 Juni 1963. Saat iini bekerja sebagai Fungsional Peneliti dengan jabatan Peneliti Utama golongan IV/d pada Badan Penelitian dan Pengembangan Kementerian Dalam Negeri. Menyelesaikan pendidikan di APMD di Yogyakarta pada 1987 dan pendidikan di STPMD Yogyakarta pada 1990.

\section{Hayat Abdullah}

Lahir di Kabupaten Sampang pada tanggal 15 Agustus 1982. Saat ini bekerja sebagai dosen tetap pada Program Studi Ilmu Adminisrtrasi Negara Fakultas Ilmu Administrasi (FIA) Universitas Islam Malang (Unisma) dan Peneliti di Research Center for Local Government (RECELGO) FIA Unisma. Menamatkan pendidikan S1 di Universitas Islam Malang pada Fakultas Ilmu Administrasi Program Studi Ilmu Administrasi Negara tahun 2007 dan S2 diselesaikan pada tahun 2012 di Universitas Merdeka Malang pada Program Pascasarjana Magister Administrasi Publik dengan Konsentrasi Kebijakan Publik.

\section{Mohammad Zainul Abidin}

Lahir di Malang pada 8 November 1978. Saat ini bekerja pada Kementerian Keuangan sebagai Fungsional Peneliti bidang kepakaran Ekonomi Terapan. Menyelesaikan pendidikan D4 Akuntansi di Sekolah Tinggi Akuntansi Negara dan pendidikan Magister Hukum Bisnis di Universitas Gajah Mada pada tahun 2009.

\section{Teguh Narutomo}

Lahir di Pontianak, 17 Juli 1968, Pangkat Penata Tk. I (III/d). Jabatan sekarang sejak tahun 2010: Peneliti Madya Golongan IV/a Bidang Kebijakan Publik yang merupakan impassing dari fungsional Dosen STPDN tahun 2004 dengan pangkat Fungsional Asisten Ahli dan kemudian tahun 2006 menjadi Fungsional Lektor. Terhitung mulai tahun 1997 sudah mengikuti penelitian kebijakan publik yang bekerja sama dengan pemerintah daerah, seperti:
Rencana Strategis Kabupaten Bekasi, Penataan Daerah Kabupaten Tangerang, Penataan Daerah Kabupaten Bandung, Tipologi Kecamatan dan Kelurahan Kota Tangerang, Penataan Daerah Provinsi Jawa Barat, Wacana Calon Kabupaten Malingping di Kabupaten Lebak, Pemekaran Wilayah Kabupaten Pandeglang, Wacana Pemekaran Wilayah di Kabupaten Kutai Kartanegara, Kajian Pemekaran Wilayah di Kabupaten Ogan Komering Ilir, dan lain-lain.

\section{Imam Radianto Anwar Setia Putra}

Lahir di Sei Geringging, 11 Februari 1983. Pendidikan terakhir Magister Manajemen pada Universitas Negeri Padang (UNP) pada tahun 2007. Sejak tahun 2008 mengikuti kegiatan penelitian pada BPP kemendagri dan pada tahun 2011 menjadi peneliti bidang kebijakan publik pada Pusat Penelitian Dan Pengembangan Kesatuan Bangsa Politik Dan Otonomi Daerah.

\section{Djoko Sulistyono}

Lahir di Jakarta pada 1 Oktober 1961. Saat ini bekerja sebagai Fungsional Peneliti di Pusat Penelitian Pemerintahan Umum dan Kependudukan pada Badan Penelitian dan Pengembangan Kementerian Dalam Negeri sejak 1999 sampai dengan sekarang. Menyelesaikan pendidikan sarjana Hubungan Internasional Fakultas Ilmu Sosial dan Ilmu Politik Universitas Padjadjaran Bandung pada tahun 2988 dan pendidikan magister Ilmu Politik Universitas Indonesia Jakarta pada 2002. 



\title{
Pedoman Penulisan
}

1. Artikel ditulis dengan bahasa Indonesia atau bahasa Inggris dalam bidang kajian pemerintahan dalam negeri/pemerintahan daerah.

2. Substansi artikel diharapkan sejalan dengan Panduan Akreditasi Berkala Ilmiah, yang diterbitkan Badan Penelitian dan Pengembangan Kementerian Dalam Negeri. http://www.bpp.depdagri.go.id/....

3. Artikel ditulis dengan kaidah tata bahasa Inggris ataupun bahasa Indonesia yang baku, baik, dan benar.

4. Sistematika Penulisan

Sistematika penjenjangan atau peringkat judul artikel dan bagian-bagiannya dilakukan dengan cara berikut:

(1) Judul ditulis dengan huruf besar semua, di bagian tengah atas pada halaman pertama;

(2) Sub Bab Peringkat 1 ditulis dengan huruf pertama besar semua rata tepi kiri;

(3) Sub Bab Peringkat 2 ditulis dengan huruf besar-kecil rata tepi kiri.

- Sistematika artikel hasil penelitian adalah: judul; nama penulis (tanpa gelar akademik); nama dan alamat institusi, alamat e-mail penulis, abstrak (maksimum 150 kata dalam bahasa Inggris dan 250 kata dalam bahasa Indonesia) yang berisi tujuan, metode, dan hasil penelitian; kata kunci (4-5 kata kunci); pendahuluan (tanpa ada subjudul) yang berisi latar belakang, sedikit tinjauan pustaka, dan tujuan penelitian; metode; hasil penelitian dan pembahasan; simpulan; daftar rujukan (hanya memuat sumber-sumber yang dirujuk).

\section{JUDUL (ringkas dan lugas; maksimal 14 kata, hindari kata “analisis”, “studi”, “pengaruh”)}

Penulis $1^{1}$ dan Penulis $2^{2}$

${ }^{1}$ Nama instansi/lembaga Penulis 1

Alamat lengkap instansi penulis, nomor telepon instansi penulis

${ }^{2}$ Nama instansi/lembaga Penulis 2

Alamat lengkap instansi penulis, nomor telepon instansi penulis

(jika nama instansi penulis 1 dan 2 sama, cukup ditulis satu saja)

E-mail penulis 1 dan 2:

Abstract: Abstract in english (max. 150 words)

Keywords: 4 - 5 words/ phrase (separated with ;)

Abstrak: Abstrak dalam bahasa Indonesia (maks. 250 kata)

Kata kunci: 4 - 5 kata/ frasa (dipisahkan dengan ;)

\section{PENDAHULUAN}

(berisi latar belakang, sekilas tinjauan pustaka, dan tujuan penelitian, yang dimasukkan dalam paragraf-paragraf bukan dalam bentuk subbab)

\author{
METODE PENELITIAN \\ Subbab
}

...

\section{HASIL DAN PEMBAHASAN}

(Hasil adalah gambaran lokus. Pembahasan adalah analisa dan interpretasi penulis)

Subbab

...

\section{SIMPULAN}

(Simpulan adalah hasil dari pembahasan yang menjawab permasalahan penelitian)

\section{DAFTAR PUSTAKA}


- Sistematika artikel hasil pemikiran/reviu/telaahan adalah: judul; nama penulis (tanpa gelar akademik); nama dan alamat institusi, alamat e-mail penulis, abstrak (maksimum 150 kata dalam bahasa Inggris dan 25 kata dalam bahasa Indonesia); kata-kata kunci (4-5 kata kunci); pendahuluan (tanpa ada subjudul) yang berisi latar belakang dan tujuan atau ruang lingkup tulisan; bahasan utama (dapat dibagi ke dalam beberapa sub-judul); simpulan; daftar rujukan (hanya memuat sumber-sumber yang dirujuk).

\section{JUDUL}

\section{Penulis}

Nama instansi/lembaga Penulis

Alamat lengkap instansi penulis, nomor telepon instansi penulis E-mail penulis

Abstract: Abstract in English (max. 150 words)

Keywords: $4-5$ words/ phrase

Abstrak: Abstrak dalam bahasa Indonesia (maks. 250 kata)

Kata kunci: 4 - 5 kata/ frasa

\section{PENDAHULUAN \\ PEMBAHASAN \\ PENUTUP \\ DAFTAR PUSTAKA}

5. Artikel diketik pada kertas ukuran A4 berkualitas baik. Dibuat sesingkat mungkin sesuai dengan subyek dan metode penelitian (bila naskah tersebut ringkasan penelitian), biasanya 20-25 halaman dengan spasi satu, untuk kutipan paragraf langsung diindent (tidak termasuk daftar pustaka).

6. Abstrak, ditulis satu paragraf sebelum isi naskah. Abstrak dalam dua bahasa yaitu bahasa Indonesia dan bahasa Inggris. Abstrak tidak memuat uraian matematis, dan mencakup esensi utuh penelitian, metode dan pentingnya temuan dan saran atau kontribusi penelitian.

7. a. Penulisan numbering kalimat pendek diintegrasikan dalam paragraf, contohnya:

Tujuan dilakukannya penelitian ini adalah: (1) Untuk mengetahui apakah CSR berpengaruh positif terhadap nilai perusahaan; (2) Untuk mengetahui apakah persentase kepemilikan manajemen berperan sebagai variabel moderating dalam hubungan antara CSR dengan nilai perusahaan; dan (3) Untuk mengetahui apakah tipe industri berperan sebagai variabel moderating dalam hubungan antara CSR dengan nilai perusahaan?

b. Penulisan bullet juga diintegrasikan dalam paragraf dengan menggunakan tanda titik koma pada antarkata/kalimat tanpa bullet.

8. Tabel dan gambar, untuk tabel dan gambar (grafik) sebagai lampiran dicantumkan pada halaman sesudah teks. Sedangkan tabel atau gambar baik di dalam naskah maupun bukan harus diberi nomor urut.

a. Tabel atau gambar harus disertai judul. Judul tabel diletakkan di atas tabel sedangkan judul gambar diletakkan di bawah gambar.

b. Sumber acuan tabel atau gambar dicantumkan di bawah tabel atau gambar.

c. Garis tabel yang dimunculkan hanya pada bagian header dan garis bagian paling bawah tabel sedangkan untuk garis-garis vertikal pemisah kolom tidak dimunculkan.

d. Tabel atau gambar bisa diedit dan dalam tampilan berwarna yang representatif.

e. Ukuran resolusi gambar minimal $300 \mathrm{dpi}$.

Contoh Penyajian Tabel:

Tabel 1. Bentuk-Bentuk Mobilitas Penduduk

\begin{tabular}{cccc}
\hline No. & Bentuk Mobilitas & Batas Wilayah & \multicolumn{1}{c}{ Batas Waktu } \\
\hline 1. & Ulang-alik (commuting) & Dukuh & 6 jam atau lebih, kembali pada hari yang sama \\
2. & Mondok di daerah tujuan & Dukuh & Lebih dari satu hari tetapi kurang dari 6 bulan \\
3. & Menetap di daerah tujuan & Dukuh & 6 bulan atau lebih menetap di daerah tujuan \\
\hline \multicolumn{2}{l}{ Sumber: Ida Bagoes, 2000}
\end{tabular}




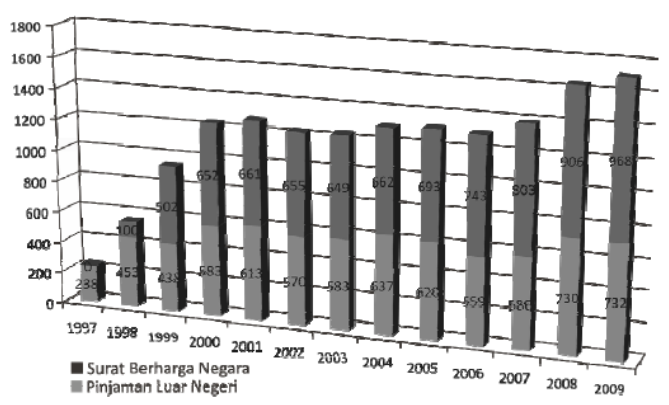

Sumber: Bank Indonesia, 2009

Gambar 1. Utang Indonesia (dalam triliun Rupiah)

9. Cara penulisan rumus. Persamaan-persamaan yang digunakan disusun pada baris terpisah dan diberi nomor secara berurutan dalam parentheses (justify) dan diletakkan pada margin kanan sejajar dengan baris tersebut. Contoh: $\mathrm{wt}=\mathrm{f}(\mathrm{yt}, \mathrm{kt}, \mathrm{wt}-1)$

10. Keterangan rumus ditulis dalam satu paragraf tanpa menggunakan simbol sama dengan (=), masingmasing keterangan notasi rumus dipisahkan dengan koma. Contoh:

dimana w adalah upah nominal, yt adalah produktivitas pekerja, kt adalah intensitas modal, wt-1 adalah tingkat upah periode sebelumnya

11. Perujukan sumber acuan di dalam teks (body text) dengan menggunakan nama akhir dan tahun. Kemudian bila merujuk pada halaman tertentu, penyebutan halaman setelah penyebutan tahun dengan dipisah titik dua. Untuk karya terjemahan dilakukan dengan cara menyebutkan nama pengarang aslinya.

Contoh:

- Buiter (2007:459) berpendapat bahwa...

- Fatimah dan Daryono (1997) menunjukkan adanya...

- Didit $d k k$ (2007) berkesimpulan bahwa...

- Untuk meningkatkan perekonomian daerah... (Yuni, Triyono, dan Agung Riyardi, 2009)

- Maya (2009) berpendapat bahwa...

12. Setiap kutipan harus diikuti sumbernya (lihat poin no.11) dan dicantumkan juga dalam daftar pustaka. Contoh:

Di dalam paragraf isi (Body Text) ada kutipan:

Buiter (2007:459) berpendapat bahwa...

Maka sumber kutipan tersebut wajib dicantumkan/disebutkan di dalam daftar pustaka:

Buiter, W.H. 2007. The Fiscal Theory of the Price Level: A Critique, Economic Journal. 112(127):459

13. Sedapat mungkin pustaka-pustaka yang dijadikan rujukan adalah pustaka yang diterbitkan 10 tahun terakhir dan diutamakan lebih banyak dari Jurnal Ilmiah (50 persen). Penulis disarankan untuk merujuk artikel-artikel pada Jurnal Bina Praja dari edisi sebelumnya.

14. Unsur yang ditulis dalam daftar pustaka secara berturut-turut meliputi: (1) nama akhir pengarang, nama awal, nama tengah, tanpa gelar akademik; (2) tahun penerbitan; (3) judul termasuk subjudul; (4) tempat penerbitan; dan (5) nama penerbit.

Contoh cara penulisan:

a. Format rujukan dari buku: Nama pengarang. (tahun). Judul Buku. Edisi. Kota penerbit: Nama penerbit.

Jika penulis sebagai editor tunggal, ditulis (Ed.) di belakang namanya. Ditulis (Eds.) jika editornya lebih dari satu orang. Kemudian bila pengarang lebih dari tiga orang, dituliskan nama pengarang pertama dan yang lain disingkat ' $d k k$ ' (pengarang domestik) atau 'et.al' (pengarang asing)

Enders, W. 2004. Applied Econometric Time Series. Second edition. New York: John Wiley \& Son.

Purnomo, Didit (Ed.). 2005. The Role of Macroeconomic Factors in Growth. Surakarta: Penerbit Muhammadiyah University Press

b. Format rujukan dari artikel dalam buku ditulis: Nama editor (Ed.). (tahun). Judul tulisan/karangan. Judul buku. hlm atau pp. kota penerbit: nama penerbit.

Daryono (Ed.). 2005. Concept of Fiscal Decentralization and Worldwide Overview (hlm. 12-25). Surakarta: Penerbit Muhammadiyah University Press. 
c. Format rujukan dari artikel dalam jurnal/majalah/koran: Nama pengarang (tahun). judul tulisan/karangan. Nama jurnal/majalah/koran. volume (nomor): halaman. Jika rujukan koran tanpa penulis, nama koran ditulis diawal

Rodden, J. 2002. The Dilemma of Fiscal Federalism: Grants and Fiscal Performance around the World. American Economic Journal. 46 (3): 670. Nashville: American Economic Association.

Triyono. 2008. Perimbangan Keuangan Pusat dan Daerah Sebagai Pelaksanaan Desentralisasi Fiskal Efek. Warta Ekonomi. Vol. 4. Agustus: 46-48

Haryanto, S. 2007, 13 November. Desentralisasi Fiskal dan Pembangunan Ekonomi. Harian Jakarta. hlm.4.

Harian Jogjakarta. 2007, 1 April. Hubungan Keuangan Pusat-Daerah di Indonesia. hlm.4.

d. Format rujukan dari internet, tanggal akses dicantumkan.

Setyowati, E. Keuangan Publik dan Sistem Harga. http://www.ekonomipublik.com/akt/pdf/ akt452.pdf. Diakses tanggal 27 Mei 2009.

15. Referensi Online yang dianjurkan dalam penggunaan bahasa Indonesia:

a. Glosarium kata baku dari Pusat Bahasa Departemen Pendidikan Nasional Republik Indonesia: http://pusatbahasa.diknas.go.id/glosarium/

b. Kamus Besar Bahasa Indonesia dari Pusat Bahasa Departemen Pendidikan Nasional Republik Indonesia: http://pusatbahasa.depdiknas.go.id/kbbi/

c. Pedoman Umum Ejaan Bahasa Indonesia yang Disempurnakan (EYD): http://pusatbahasa.depdiknas.go.id/lamanv4/sites/default/files/EJD-KKP-PBNBID.PENGEMBANGAN.pdf

\title{
Pengiriman Artikel
}

1. Artikel dikirimkan sebanyak 2 eksemplar hardcopy, dan softcopy berupa file. File bisa dikirim melalui email jurnalbinapraja@yahoo.com atau dalam media cd.

2. Artikel yang dikirim wajib dilampiri biodata ringkas pendidikan termasuk catatan riwayat karya-karya ilmiah sebelumnya yang pernah dipublikasikan, insitusi dan alamatnya, nomor telpon kontak atau e-mail penulis.

3. Penulis yang menyerahkan artikelnya harus menjamin bahwa naskah yang diajukan tidak melanggar hak cipta, belum dipublikasikan atau telah diterima untuk dipublikasi oleh jurnal lainnya.

4. Kepastian naskah dimuat atau tidak, akan diberitahukan secara tertulis. Artikel yang tidak dimuat tidak akan dikembalikan.

\author{
Alamat Jurnal Bina Praja: \\ Badan Penelitian dan Pengembangan \\ Kementerian Dalam Negeri \\ Jalan Kramat Raya No. 132, Senen - Jakarta 10420 \\ Telepon/Fax: +62 213101953 / +62 213924451 \\ e-mail: jurnalbinapraja@yahoo.com
}

